\title{
Calcium Orthophosphates: Occurrence, Properties and Major Applications
}

\section{Sergey V. Dorozhkin*}

Kudrinskaja sq. 1-155, Moscow 123242, Russia

\begin{abstract}
The present overview is intended to point the readers' attention to the important subject of calcium orthophosphates. They are of the special significance for the human beings because they represent the inorganic part of major normal (bones, teeth and antlers) and pathological (i.e., those appearing due to various diseases) calcified tissues of mammals. Therefore, the majority of the artificially prepared calcium orthophosphates of high purity appear to be well tolerated by human tissues in vivo and possess the excellent biocompatibility, osteoconductivity and bioresorbability. These biomedical properties of calcium orthophosphates are widely used to construct bone grafts. In addition, natural calcium orthophosphates are the major source of phosphorus, which are used to produce agricultural fertilizers, detergents and various phosphorus-containing chemicals. Thus, there is a great significance of calcium orthophosphates for the humankind and, here, an overview on the current knowledge on this subject is provided.
\end{abstract}

Keywords: Calcium orthophosphates; Hydroxyapatite; Fluorapatite; Occurrence; Properties; Applications

\section{Introduction}

Due to the abundance in nature (as phosphate ores) and presence in living organisms (as bones, teeth, deer antlers and the majority of various pathological calcifications), calcium orthophosphates are the inorganic compounds of a special interest for human being. They were discovered in 1769 and have been investigated since then [1,2]. According to the databases of scientific literature (Web of knowledge, Scopus, Medline, etc.), the total amount of currently available publications on the subject exceeds 40,000 with the annual increase for, at least, 2000 papers. This is a clear confirmation of the importance.

Briefly, by definition, all calcium orthophosphates consist of three major chemical elements: calcium (oxidation state +2 ), phosphorus (oxidation state +5 ) and oxygen (reduction state -2 ), as a part of the orthophosphate anions. These three chemical elements are present in abundance on the surface of our planet: oxygen is the most widespread chemical element of the earth's surface ( 47 mass \%), calcium occupies the fifth place $(\sim 3.3-3.4$ mass $\%)$ and phosphorus $(\sim 0.08-$ 0.12 mass \%) is among the first twenty of the chemical elements most widespread on our planet [3]. In addition, the chemical composition of many calcium orthophosphates includes hydrogen, as an acidic orthophosphate anion (for example, $\mathrm{HPO}_{4}{ }^{2-}$ or $\mathrm{H}_{2} \mathrm{PO}_{4}^{-}$), hydroxide (for example, $\mathrm{Ca}_{10}\left(\mathrm{PO}_{4}\right)_{6}(\mathrm{OH})_{2}$ ) and/or incorporated water (for example, $\mathrm{CaHPO}_{4} \cdot 2 \mathrm{H}_{2} \mathrm{O}$ ). Regarding their chemical composition, diverse combinations of $\mathrm{CaO}$ and $\mathrm{P}_{2} \mathrm{O}_{5}$ oxides (both in the presence of water and without it) provide a large variety of calcium phosphates, which are differentiated by the type of the phosphate anion. Namely, ortho$\left(\mathrm{PO}_{4}^{3-}\right)$, meta- $\left(\mathrm{PO}_{3}^{-}\right)$, pyro- $\left(\mathrm{P}_{2} \mathrm{O}_{7}^{4-}\right)$ and poly- $\left(\left(\mathrm{PO}_{3}\right)_{n}{ }^{\mathrm{n}}{ }^{-}\right)$phosphates are known. Furthermore, in the case of multi-charged anions (valid for orthophosphates and pyrophosphates), the calcium phosphates are also differentiated by the number of hydrogen ions attached to the anion. Examples include mono- $\left(\mathrm{Ca}\left(\mathrm{H}_{2} \mathrm{PO}_{4}\right)_{2}\right)$, di- $\left.(\mathrm{CaHPO})_{4}\right)$, tri- $\left(\mathrm{Ca}_{3}\left(\mathrm{PO}_{4}\right)_{2}\right)$ and tetra- $\left(\mathrm{Ca}_{2} \mathrm{P}_{2} \mathrm{O}_{7}\right)$ calcium phosphates. Here, one must stress that prefixes "mono", "di", "tri" and "tetra" are related to the amount of hydrogen ions replaced by calcium [4-6]. However, to narrow the subject, calcium orthophosphates will be considered and discussed only. Their names, the standard abbreviations, chemical formulae and solubility values are listed in Table $1[7,8]$. Since all of them belong to calcium orthophosphates, strictly speaking, all abbreviations in Table 1 are incorrect; however, they have been extensively used in literature for decades and, to avoid any confusions, there is no need to modify them.
In general, the atomic arrangement of all calcium orthophosphates is built up around a network of orthophosphate $\left(\mathrm{PO}_{4}\right)$ groups, which stabilize the entire structure. Therefore, the majority of calcium orthophosphates are sparingly soluble in water Table 1; however, all of them are easily soluble in acids but insoluble in alkaline solutions. In addition, all chemically pure calcium orthophosphates are colorless transparent crystals of moderate hardness but, as powders, they are of white color. Nevertheless, natural minerals of calcium orthophosphates are always colored due the presence of impurities and dopants, such as ions of $\mathrm{Fe}, \mathrm{Mn}$ and rare earth elements $[9,10]$. Biologically formed calcium orthophosphates are the major component of all mammalian calcified tissues [11], while the geologically formed ones are the major raw material to produce phosphorus-containing agricultural fertilizers, chemicals and detergents [12-14].

\section{Geological and Biological Occurrences}

Geologically, natural calcium orthophosphates are found in different regions mostly as deposits of apatites, mainly as ion-substituted FA (igneous rocks), and phosphorites (sedimentary rocks) [13-15]. In addition, natural ion-substituted CDHA was also found [16] but it is a very rare mineral. Some types of sedimentary rocks can be formed by weathering of igneous rocks into smaller particles [17]. Other types of sedimentary rocks can be composed of minerals precipitated from the dissolution products of igneous rocks or minerals produced by biomineralization Figure 1 [18]. Thus, due to a sedimentary origin, both a general appearance and a chemical composition of natural phosphorites vary a lot $[19,20]$. It is a common practice to consider francolite (or carbonate-hydroxyfluorapatite regarded as its synonym) as the basic phosphorite mineral [15,21-24]. According to Henry [25], the name francolite was given by Mr. Brooke and Mr. Nuttall to a mineral from Wheal Franco, Tavistock, Devon, some years prior to 1850. A

${ }^{*}$ Corresponding author: Sergey V. Dorozhkin, Kudrinskaja sq. 1-155, Moscow 123242, Russia, E-mail: sedorozhkin@yandex.ru

Received October 01, 2014; Accepted October 20, 2014; Published October 27, 2014

Citation: Dorozhkin SV (2014) Calcium Orthophosphates: Occurrence, Properties and Major Applications. Bioceram Dev Appl 4: 081. doi: 10.4172/2090-5025.1000081

Copyright: ( 2014 Dorozhkin SV This is an open-access article distributed under the terms of the Creative Commons Attribution License, which permits unrestricted use, distribution, and reproduction in any medium, provided the original author and source are credited. 
Citation: Dorozhkin SV (2014) Calcium Orthophosphates: Occurrence, Properties and Major Applications. Bioceram Dev Appl 4: 081. doi: 10.4172/2090-5025.1000081

Page 2 of 20

\begin{tabular}{|c|c|c|c|c|c|}
\hline $\mathrm{Ca} / \mathrm{P}$ molar ratio & Compound & Formula & $\begin{array}{l}\text { Solubility at } \\
25^{\circ} \mathrm{C},-\log \left(\mathrm{K}_{\mathrm{s}}\right)\end{array}$ & $\begin{array}{l}\text { Solubility at } \\
25^{\circ} \mathrm{C}, \mathrm{g} / \mathrm{L}\end{array}$ & $\begin{array}{c}\text { pH stability range in aqueous } \\
\text { solutions at } 25^{\circ} \mathrm{C}\end{array}$ \\
\hline 0.5 & $\begin{array}{l}\text { Monocalcium phosphate monohydrate } \\
\text { (MCPM) }\end{array}$ & $\mathrm{Ca}\left(\mathrm{H}_{2} \mathrm{PO}_{4}\right)_{2} \cdot \mathrm{H}_{2} \mathrm{O}$ & 1.14 & $\sim 18$ & $0.0-2.0$ \\
\hline 0.5 & $\begin{array}{l}\text { Monocalcium phosphate anhydrous } \\
\text { (MCPA or MCP) }\end{array}$ & $\mathrm{Ca}\left(\mathrm{H}_{2} \mathrm{PO}_{4}\right)_{2}$ & 1.14 & $\sim 17$ & [c] \\
\hline 1.0 & $\begin{array}{l}\text { Dicalcium phosphate dihydrate (DCPD), } \\
\text { mineral brushite }\end{array}$ & $\mathrm{CaHPO}_{4} \cdot 2 \mathrm{H}_{2} \mathrm{O}$ & 6.59 & $\sim 0.088$ & $2.0-6.0$ \\
\hline 1.0 & $\begin{array}{c}\text { Dicalcium phosphate anhydrous (DCPA } \\
\text { or DCP), mineral monetite }\end{array}$ & $\mathrm{CaHPO}_{4}$ & 6.90 & $\sim 0.048$ & [c] \\
\hline 1.33 & Octacalcium phosphate (OCP) & $\mathrm{Ca}_{8}\left(\mathrm{HPO}_{4}\right)_{2}\left(\mathrm{PO}_{4}\right)_{4} \cdot 5 \mathrm{H}_{2} \mathrm{O}$ & 96.6 & $\sim 0.0081$ & $5.5-7.0$ \\
\hline 1.5 & $\alpha-$ Tricalcium phosphate $(\alpha-T C P)$ & $\alpha-\mathrm{Ca}_{3}\left(\mathrm{PO}_{4}\right)_{2}$ & 25.5 & $\sim 0.0025$ & [a] \\
\hline 1.5 & $\beta$-Tricalcium phosphate ( $\beta$-TCP) & $\beta-\mathrm{Ca}_{3}\left(\mathrm{PO}_{4}\right)_{2}$ & 28.9 & $\sim 0.0005$ & [a] \\
\hline $1.2-2.2$ & Amorphous calcium phosphates (ACP) & $\begin{array}{c}\mathrm{Ca}_{x} \mathrm{H}_{y}\left(\mathrm{PO}_{4}\right)_{z} \cdot n \mathrm{H}_{2} \mathrm{O}, n=3-4.5 ; 15- \\
20 \% \mathrm{H}_{2} \mathrm{O}\end{array}$ & {$[b]$} & [b] & $\sim 5-12^{[\mathrm{d}]}$ \\
\hline $1.5-1.67$ & $\begin{array}{c}\text { Calcium-deficient hydroxyapatite (CDHA } \\
\text { or Ca-def } \mathrm{HA})^{[\mathrm{e}]}\end{array}$ & $\mathrm{Ca}_{10-x}\left(\mathrm{HPO}_{4}\right)_{x}\left(\mathrm{PO}_{4}\right)_{6-x}(\mathrm{OH})_{2-x}(0<x<1)$ & $\sim 85$ & $\sim 0.0094$ & $6.5-9.5$ \\
\hline 1.67 & Hydroxyapatite (HA, HAp or OHAp) & $\mathrm{Ca}_{10}\left(\mathrm{PO}_{4}\right)_{6}(\mathrm{OH})_{2}$ & 116.8 & $\sim 0.0003$ & $9.5-12$ \\
\hline 1.67 & Fluorapatite (FA or FAp) & $\mathrm{Ca}_{10}\left(\mathrm{PO}_{4}\right)_{6} \mathrm{~F}_{2}$ & 120.0 & $\sim 0.0002$ & $7-12$ \\
\hline 1.67 & $\begin{array}{c}\text { Oxyapatite }(\mathrm{OA}, \text { OAp or OXA })^{[f]} \text {, mineral } \\
\text { voelckerite }\end{array}$ & $\mathrm{Ca}_{10}\left(\mathrm{PO}_{4}\right)_{6} \mathrm{O}$ & $\sim 69$ & $\sim 0.087$ & [a] \\
\hline 2.0 & $\begin{array}{l}\text { Tetracalcium phosphate (TTCP or } \\
\text { TetCP), mineral hilgenstockite }\end{array}$ & $\mathrm{Ca}_{4}\left(\mathrm{PO}_{4}\right)_{2} \mathrm{O}$ & $38-44$ & $\sim 0.0007$ & [a] \\
\hline
\end{tabular}

[a] These compounds cannot be precipitated from aqueous solutions.

${ }^{[b]}$ Cannot be measured precisely. However, the following values were found: $25.7 \pm 0.1(\mathrm{pH}=7.40), 29.9 \pm 0.1(\mathrm{pH}=6.00), 32.7 \pm 0.1(\mathrm{pH}=5.28)[236]$. The comparative

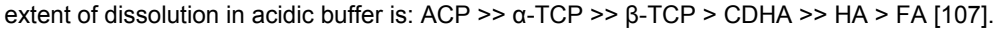

${ }^{\text {[c] }}$ Stable at temperatures above $100^{\circ} \mathrm{C}$.

${ }^{[d]}$ Always metastable.

[e] Occasionally, it is called "precipitated HA (PHA)".

[f] Existence of $\mathrm{OA}$ remains questionable

Table 1: Existing calcium orthophosphates and their major properties $[7,8]$.

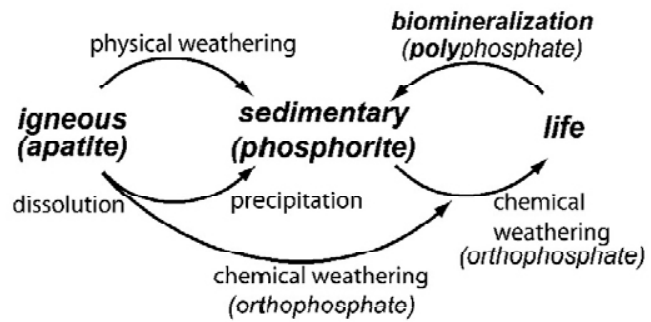

Figure 1: Simplified schematic of the phosphorus cycle from apatitic igneous rock to phosphorite sedimentary rock through chemical or physical weathering. Life forms accumulate soluble phosphorus species and can produce apatite through biomineralization. Reprinted from Ref [18] with permission.

cryptocrystalline (almost amorphous) variety of francolite (partly of a biological origin) is called collophane (synonyms: collophanit, collophanita, collophanite, grodnolite, kollophan) [26-28]. It occurs in natural phosphorites predominantly as fossil bones and phosphatized microbial pseudomorphs: phosphatic crusts of chasmolithic biofilms (or microstromatolites) and globular clusters with intra-particular porosities [29-32]. Natural phosphorites (therefore, francolite and collophane as well) occur in various forms, such as nodules, crystals or masses. Occasionally, other types of natural calcium orthophosphates are found as minerals, for example clinohydroxylapatite [33], staffelite (synonyms: staffelit, staffelita) belonging to carbonate-rich fluorapatites (chemical formula: $\left.\mathrm{Ca}_{5}\left[(\mathrm{~F}, \mathrm{O})\left(\mathrm{PO}_{4}, \mathrm{CO}_{3}\right)_{3}\right]\right)[34,35]$ and DCPD [36]. Furthermore, calcium orthophosphates were found in meteoric stones $[37,38]$. The world deposits of natural calcium orthophosphates are estimated to exceed 150 billion tons; from which approximately $85 \%$ belong to phosphorites and the remaining $~ 15 \%$ belong to apatites.
As minor constituents $(<\sim 5 \%)$, natural calcium orthophosphates (both apatites and phosphorites) occur in many geological environments. Concentrations sufficient for economic use (> 15\%) are also available. Namely, the largest world deposits of natural apatites are located in Russia (the Khibiny and Kovdor massifs, Kola peninsula [39,40]), Brazil and Zambia, while the largest world deposits of natural phosphorites are located in Morocco, Russia, Kazakhstan, USA (Florida, Tennessee), China and Australia [12-15]. In addition, they are found at seabed and ocean floor [41]. The majority of natural calcium orthophosphates occur as small polycrystalline structures (spherulitic clusters). Larger crystals are rare [42]. They usually have the crystal structure of apatites (hexagonal system, space group $\mathrm{P6}_{3} / \mathrm{m}$ ). Giant crystals including "a solid but irregular mass of green crystalline apatite, 15 feet long and 9 feet wide" [43] and a single euhedral crystal from the Aetna mine measuring $2.1 \times 1.2 \mathrm{~m}$ with an estimated weight of 6 tons [44] were found. None of them is a pure compound; they always contain dopants of other elements. For example, ions of calcium might be partially replaced by $\mathrm{Sr}, \mathrm{Ba}, \mathrm{Mg}, \mathrm{Mn}, \mathrm{K}, \mathrm{Na}, \mathrm{Fe}$; ions of orthophosphate may be partly replaced by $\mathrm{AsO}_{4}{ }^{3-}, \mathrm{CO}_{3}{ }^{2-}$ and $\mathrm{VO}_{4}^{3-}[45]$; ions of hydroxide, chloride, bromide, carbonate and oxide may to a certain extent substitute fluoride in the crystal lattice of natural apatites [23]. Furthermore, organic radicals have been found in natural apatites $[46,47]$. In principle, the crystal structure of apatites can incorporate half the Periodic Chart in its atomic arrangement. In medicine, this property might be used as an antidote for heavy metal intoxication [48]. Ease of atomic substitution for apatite leaves this mineral open to a wide array of compositions. This might be related to the fact that the apatite structure type displays porous properties [49]. The substitutions in apatites are usually in trace concentrations but for certain dopants large concentrations and even complete solid solutions exist (e.g., F- 
and $\mathrm{OH}^{-}$). To make things even more complicated, some ions in the crystal structure may be missing, leaving the crystallographic defects, which leads to formation of non-stoichiometric compounds, such as CDHA. Figure 2 shows examples of polycrystalline and singlecrystalline samples of natural FA.

Manufacturing of elementary phosphorus (white and red) [50,51], phosphoric acids [13,52-55], various phosphorus-containing chemicals, agricultural fertilizers (namely, superphosphate [56-58], ammonium orthophosphates [59] and detergents (principally sodium tripolyphosphate [60] are the major industrial applications of natural calcium orthophosphates. The annual consumption of a phosphate rock has approached $\sim 150$ million tons and about 95 percent of this production is utilized in the fertilizer industry $[61,62]$.

In biological systems, many organisms, ranging from bacteria and isolated cells to invertebrates and vertebrates, synthesize calcium orthophosphates [18]. Formation of calcium orthophosphates in primitive organisms is believed to enable the storage and regulation of essential elements such as calcium, phosphorus and, possibly, magnesium. The morphology of precipitates in these organisms (small intracellular nodules of ACP often located in mitochondria) complies with the necessities for rapid mobilization and intracellular control of the concentration of these elements [63]. In vertebrates calcium orthophosphates occur as the principal inorganic constituent of normal (bones, teeth, fish enameloid, deer antlers and some species of shells) and pathological (dental and urinary calculus and stones, atherosclerotic lesions, etc.) calcifications [11,64-69]. Except for small portions of the inner ear, all hard tissue of the human body is formed of calcium orthophosphates. Structurally, they occur mainly in the form of poorly crystalline, non-stoichiometric, Ca-deficient, $\mathrm{Na}-, \mathrm{Mg}$ - and carbonate-containing HA. It is often called "biological apatite" [70-72] (which might be abbreviated as BAp [73,74], bioapatite [75-78e] or dahllite. The latter was named in 1888 by Broeger and Bäckstroem [79] after the Swedish mineralogist brothers Tellef and Johan Martin Dahll.

The main constituents of human bones are calcium orthophosphates $(\sim 60-70 \mathrm{wt} . \%)$, collagen $(\sim 20-30 \mathrm{wt} . \%)$ and water (up to $10 \mathrm{wt} . \%)$ $[68,75,80,81]$. Detailed information on the chemical composition of the most important human normal calcified tissues is comprised in Table 2. One should note that the values mentioned in Table 2 are approximate; the main constituents can vary by a percent or more [82].

\section{The Members of Calcium Orthophosphate Family}

In the ternary aqueous system $\mathrm{Ca}(\mathrm{OH})_{2}-\mathrm{H}_{3} \mathrm{PO}_{4}-\mathrm{H}_{2} \mathrm{O}$ (or $\mathrm{CaO}$ $-\mathrm{P}_{2} \mathrm{O}_{5}-\mathrm{H}_{2} \mathrm{O}$ ) [83-85] there are twelve known non-ion-substituted calcium orthophosphates with the $\mathrm{Ca} / \mathrm{P}$ molar ratio ranging between 0.5 and 2.0 Table 1. An anhydrous phase diagram $\mathrm{CaO}-\mathrm{P}_{2} \mathrm{O}_{5}$ at temperatures within $200-2200^{\circ} \mathrm{C}$ is shown in Figure $3[86,87]$. Table 3 comprises crystallographic data of the existing calcium orthophosphates $[5,88,89]$. The most important parameters of calcium orthophosphates are the ionic $\mathrm{Ca} / \mathrm{P}$ ratio, basicity / acidity and solubility. All these parameters strongly correlate with the solution $\mathrm{pH}$. The lower the $\mathrm{Ca} / \mathrm{P}$ molar ratio is, the more acidic and water-soluble the calcium orthophosphate is [4-6]. One can see that the solubility ranges from high values for acidic compounds, such as MCPM, to very low values for basic compounds, such as apatites, which allow calcium orthophosphates to be dissolved, transported from one place to another and precipitated, when necessary. Crystallization, dissolution and phase transformation processes of different calcium orthophosphates under various experimental conditions have been reviewed [90]. Regarding applications, some of them might be used in food industry and, according to the European classification of food additives, calcium orthophosphates of food grade quality are known as E341 additive.

Due to the triprotic equilibrium that exists within orthophosphatecontaining solutions, variations in $\mathrm{pH}$ alter the relative concentrations of the four polymorphs of orthophosphoric acid Figure 4 [91] and thus both the chemical composition Figure 5 [92] and the amount of the calcium orthophosphates that are formed by a direct precipitation. The solubility isotherms of different calcium orthophosphates are shown in Figure $6[5,6,84,85,93,94]$. However, in 2009, the classic solubility data of calcium orthophosphates $[5,6,84,85,93,94]$ were mentioned to be inappropriate [95]. According to the authors of the latter study, all previous solubility calculations were based on simplifications, which

(a)

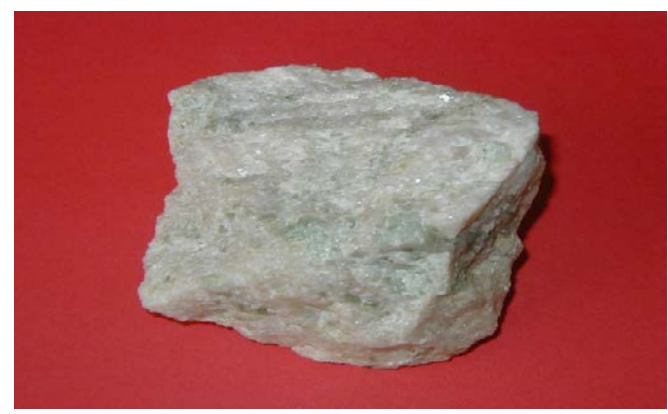

(b)

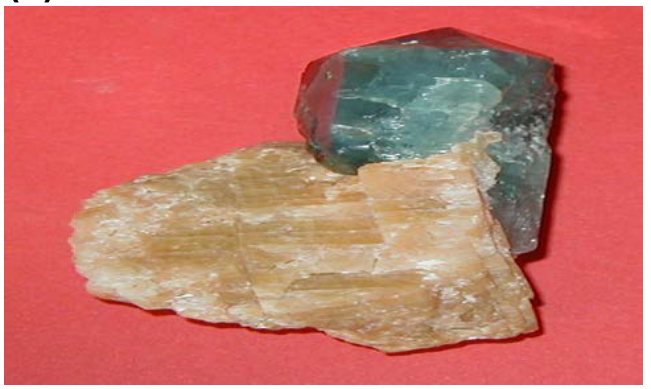

Figure 2: Polycrystalline (a) and single-crystalline (b) FA of a geological origin. The single crystal has a grey-green color due to incorporated ions of transition metals.

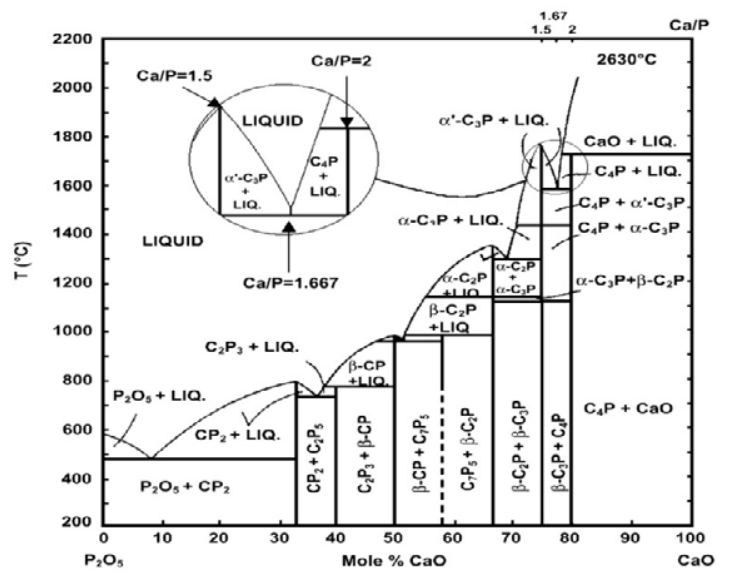

Figure 3: Phase diagram of the system $\mathrm{CaO}-\mathrm{P}_{2} \mathrm{O}_{5}\left(\mathrm{C}=\mathrm{CaO}, \mathrm{P}=\mathrm{P}_{2} \mathrm{O}_{5}\right)$ at elevated temperatures. Here: $\mathrm{C}_{7} \mathrm{P}_{5}$ means $7 \mathrm{CaO} \cdot 5 \mathrm{P}_{2} \mathrm{O}_{5}$; other abbreviations should be written out in the same manner. Reprinted from Refs. $[86,87]$ with permission. 
Citation: Dorozhkin SV (2014) Calcium Orthophosphates: Occurrence, Properties and Major Applications. Bioceram Dev Appl 4: 081. doi: 10.4172/2090-5025.1000081

Page 4 of 20

\begin{tabular}{|c|c|c|c|c|c|}
\hline Composition, wt $\%$ & Enamel & Dentine & Cementum & Bone & HA \\
\hline Calcium $^{[a]}$ & 36.5 & 35.1 & $\sim 35$ & 34.8 & 39.6 \\
\hline Phosphorus (as P) ${ }^{[\mathrm{a}]}$ & 17.7 & 16.9 & $\sim 16$ & 15.2 & 18.5 \\
\hline $\mathrm{Ca} / \mathrm{P}$ (molar ratio) ${ }^{[a]}$ & 1.63 & 1.61 & $\sim 1.65$ & 1.71 & 1.67 \\
\hline Sodium ${ }^{[a]}$ & 0.5 & 0.6 & [c] & 0.9 & - \\
\hline Magnesium $^{[\mathrm{a}]}$ & 0.44 & 1.23 & $0.5-0.9$ & 0.72 & - \\
\hline Potassium [a] & 0.08 & 0.05 & [c] & 0.03 & - \\
\hline Carbonate $\left(\text { as } \mathrm{CO}_{3}{ }^{2-}\right)^{[\mathrm{b}]}$ & 3.5 & 5.6 & [c] & 7.4 & - \\
\hline Fluoride ${ }^{[a]}$ & 0.01 & 0.06 & up to 0.9 & 0.03 & - \\
\hline Chloride ${ }^{[a]}$ & 0.30 & 0.01 & [c] & 0.13 & - \\
\hline Pyrophosphate $\left(\text { as } \mathrm{P}_{2} \mathrm{O}_{7}^{4-}\right)^{[b]}$ & 0.022 & 0.10 & [c] & 0.07 & - \\
\hline Total inorganic ${ }^{[\mathrm{b}]}$ & 97 & 70 & 60 & 65 & 100 \\
\hline Total organic ${ }^{[b]}$ & 1.5 & 20 & 25 & 25 & - \\
\hline Water ${ }^{[b]}$ & 1.5 & 10 & 15 & 10 & - \\
\hline \multicolumn{6}{|l|}{$\begin{array}{l}\text { Crystallographic properties: } \\
\text { Lattice parameters }( \pm 0.003 \AA \text { ) }\end{array}$} \\
\hline a-axis, $\AA$ & 9.441 & 9.421 & [c] & 9.41 & 9.430 \\
\hline$c$-axis, $\AA$ & 6.880 & 6.887 & [c] & 6.89 & 6.891 \\
\hline Crystallinity index $(H A=100)$ & $70-75$ & $33-37$ & $\sim 30$ & $33-37$ & 100 \\
\hline Typical crystal sizes (nm) [11] & $100 \mu \mathrm{m} \times 50 \times 50$ & $35 \times 25 \times 4$ & [c] & $50 \times 25 \times 4$ & $200-600$ \\
\hline Ignition products $\left(800^{\circ} \mathrm{C}\right)$ & $\beta-\mathrm{TCP}+\mathrm{HA}$ & $\beta-\mathrm{TCP}+\mathrm{HA}$ & $\beta-\mathrm{TCP}+\mathrm{HA}$ & $\mathrm{HA}+\mathrm{CaO}$ & $\mathrm{HA}$ \\
\hline Elastic modulus (GPa) & 80 & $23.8 \pm 3.7$ & $15.0 \pm 3.6$ & $0.34-13.8$ & 10 \\
\hline Tensile strength (MPa) & 10 & 100 & [c] & 150 & 100 \\
\hline
\end{tabular}

[a] Ashed samples.

[b] Unashed samples.

${ }^{[c]}$ Numerical values were not found in the literature but they should be similar to those for dentine.

Table 2: Comparative composition and structural parameters of inorganic phases of adult human calcified tissues. Due to the considerable variation found in biological samples, typical values are given in these cases $[4,81]$.
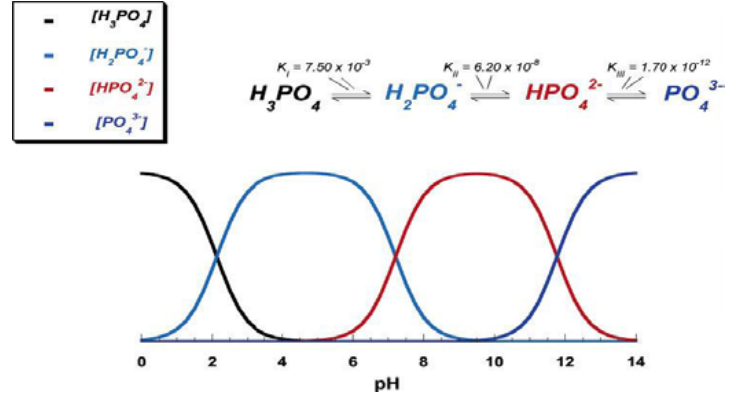

Figure 4: $\mathrm{pH}$ variation of ionic concentrations in triprotic equilibrium for phosphoric acid solutions. Reprinted from Ref. [91] with permission

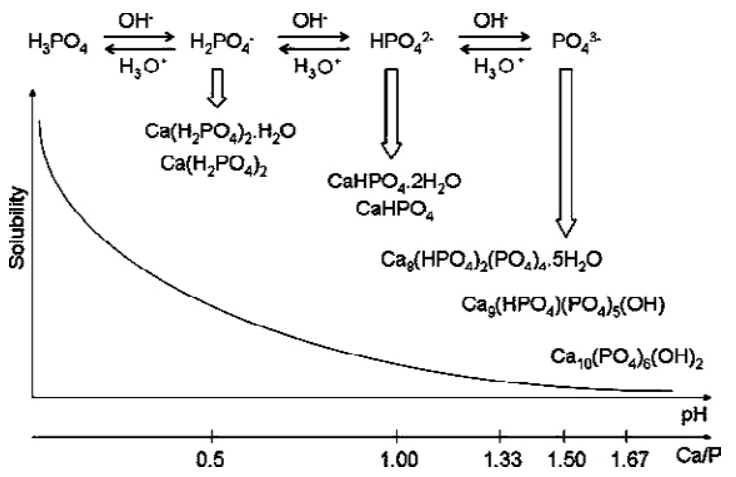

Figure 5: Various calcium orthophosphates obtained by neutralizing of orthophosphoric acid. $\mathrm{Ca} / \mathrm{P}$ are reported in the figure. The solubility of calcium orthophosphates in water decreases drastically from left to right, HA being the most insoluble and stable phase. Reprinted from Ref. [91] with permission. were only crudely approximate. The problem lies in incongruent dissolution, leading to phase transformations and lack of the detailed solution equilibria. Using an absolute solid-titration approach, the true solubility isotherm of HA was found to lie substantially lower than previously reported. In addition, contrary to a wide belief, DCPD appeared not to be the most stable phase below $\mathrm{pH} \sim 4.2$, where CDHA was less soluble [95].

A brief description of all known calcium orthophosphates Table 1 is given below.

\section{MCPM}

Monocalcium phosphate monohydrate $\left(\mathrm{Ca}\left(\mathrm{H}_{2} \mathrm{PO}_{4}\right)_{2} \cdot \mathrm{H}_{2} \mathrm{O}\right.$; the IUPAC name is calcium dihydrogen orthophosphate monohydrate) is both the most acidic and water-soluble calcium orthophosphate. Although acidic calcium orthophosphates in general were known by 1795 as "super-phosphate of lime" [96], their differentiation started in 1800-s. Namely, by 1807 , researchers first prepared a calcium phosphate, which could be attributed to MCPM [97].

MCPM crystallizes from aqueous solutions containing dissolved ions of $\mathrm{H}_{2} \mathrm{PO}_{4}^{-}$and $\mathrm{Ca}^{2+}$ at the $\mathrm{Ca} / \mathrm{P}$ ratio $\sim 0.5$ and solution $\mathrm{pH}$ below $\sim 2.0$. Besides, MCPM might be precipitated from aqueous solutions containing organic solvents $[98,99]$. At temperatures above $\sim 100^{\circ} \mathrm{C}$, MCPM releases a molecule of water and transforms into MCPA but at temperatures $>\sim 500{ }^{\circ} \mathrm{C}$ MCPA further transforms into $\mathrm{Ca}\left(\mathrm{PO}_{3}\right)_{2}$ [100]. The results of the spectroscopic investigations of MCPM are available in literature [101].

Due to high acidity and solubility, MCPM is never found in biological calcifications. Moreover, pure MCPM is not biocompatible with bones [102]. However, in medicine MCPM is used as a component 
Citation: Dorozhkin SV (2014) Calcium Orthophosphates: Occurrence, Properties and Major Applications. Bioceram Dev Appl 4: 081. doi: 10.4172/2090-5025.1000081

Page 5 of 20
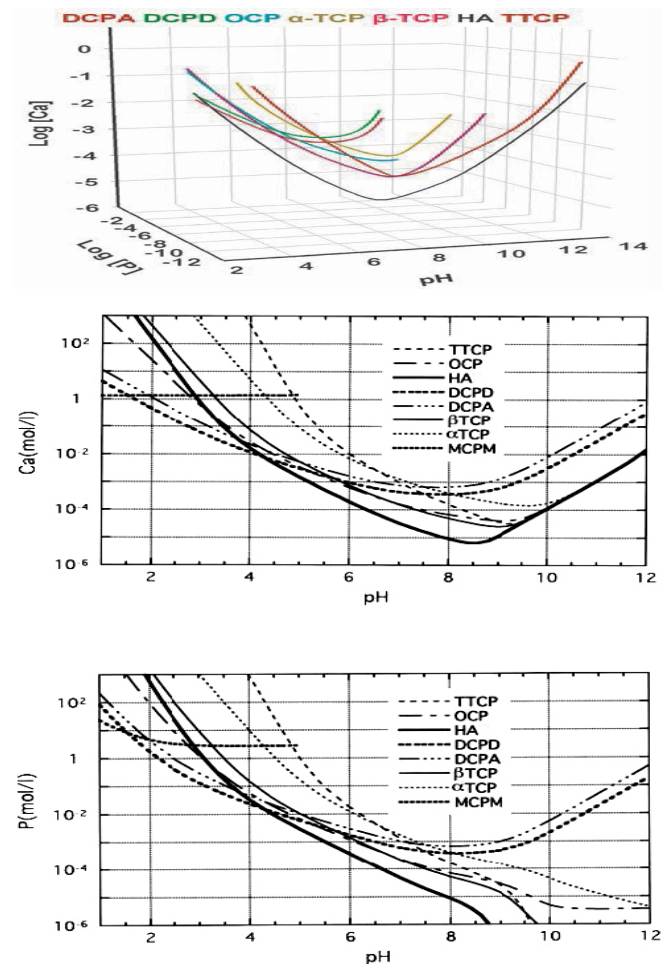

Figure 6: Top: a 3D version of the classical solubility phase diagrams for the ternary system $\mathrm{Ca}(\mathrm{OH})_{2}-\mathrm{H}_{3} \mathrm{PO}_{4}-\mathrm{H}_{2} \mathrm{O}$. Reprinted from Ref. [94] with permission. Middle and bottom: solubility phase diagrams in two-dimensional graphs, showing two logarithms of the concentrations of (a) calcium and (b) orthophosphate ions as a function of the $\mathrm{pH}$ in solutions saturated with various salts. Reprinted from Ref. [384] with permission [385].

of several self-hardening calcium orthophosphate formulations $[103,104]$. In addition, MCPM is used as a nutrient, acidulant and mineral supplement for dry baking powders, food, feed and some beverages $[105,106]$. Coupled with $\mathrm{NaHCO}_{3}, \mathrm{MCPM}$ is used as a leavening agent for both dry baking powders and bakery dough. MCPM might be added to salt-curing preserves, pickled and marinated foods. In addition, MCPM might be added to tooth pastes and chewing gums [107]. Besides, MCPM might be added to ceramics and glasses, while agriculture is the main consumer of a technical grade MCPM, where it is used as a fertilizer, triple superphosphate [108]

\section{MCPA (or MCP)}

Monocalcium phosphate anhydrous $\left(\mathrm{Ca}\left(\mathrm{H}_{2} \mathrm{PO}_{4}\right)_{2}\right.$; the IUPAC name is calcium dihydrogen orthophosphate anhydrous) is the anhydrous form of MCPM. Although MCPM has been known since 1807 [1,2], MCPA was differentiated as "tetra-hydrogen calcium phosphate, $\mathrm{H}_{4} \mathrm{Ca}\left(\mathrm{PO}_{4}\right)_{2}$ " by 1879 [109]. It crystallizes under the same conditions as MCPM but at temperatures above $\sim 100^{\circ} \mathrm{C}$ (e.g., from concentrated hot mother liquors during fertilizer production). In addition, MCPA might be prepared from MCPM by dehydration. Furthermore, it might be also prepared at ambient temperatures by crystallization in water-restricted or non-aqueous systems. Like MCPM, MCPA never appears in calcified tissues and is not biocompatible due to its acidity. There is no current application of MCPA in medicine. Due to the similarity with MCPM, in many cases, MCPA might be used instead of MCPM; however, highly hydroscopic properties of MCPA reduce its commercial applications [13,105].

\section{DCPD}

Dicalcium phosphate dihydrate $\left(\mathrm{CaHPO}_{4} \cdot 2 \mathrm{H}_{2} \mathrm{O}\right.$; the IUPAC name is calcium hydrogen orthophosphate dihydrate; the mineral brushite) has been known since, at least, 1804 [96]. As a mineral, brushite was first discovered in phosphatic guano from Avis Island (Caribbean) in 1865 [110] and named to honor an American mineralogist Prof. George Jarvis Brush (1831 - 1912), Yale University, New Haven, Connecticut, USA.

DCPD can be easily crystallized from aqueous solutions containing dissolved ions of $\mathrm{HPO}_{4}^{2-}$ and $\mathrm{Ca}^{2+}$ at the $\mathrm{Ca} / \mathrm{P}$ ratio $\sim 1$ and solution $\mathrm{pH}$ within $\sim 2.0<\mathrm{pH}<\sim 6.5$. Other preparation techniques such as neutralization of $\mathrm{H}_{3} \mathrm{PO}_{4}$ and/or MCPM solutions by $\mathrm{CaO}, \mathrm{CaCO}_{3}$ or more basic calcium orthophosphates ( $\alpha$ - or $\beta$-TCP, CDHA, HA, TTCP) are also known. Interestingly, that precipitation of DCPD by mixing a $\mathrm{Ca}(\mathrm{OH})_{2}$ suspension and $\mathrm{H}_{3} \mathrm{PO}_{4}$ solution in the equimolar quantities was found to occur in five stages, being HA the first precipitated phase $[111,112]$. Besides, DCPD might be prepared in gels $[113,114]$. DCPD transforms into DCPA at temperatures above $\sim 80^{\circ} \mathrm{C}$ and this transformation is accompanied by $\sim 11 \%$ decrease in volume [115] and structural changes [116]. The value for $\Delta_{\mathrm{r}} G^{0}$ for DCPD $\rightarrow$ DCPA transformation is $-1.032 \mathrm{~kJ} / \mathrm{mol}$ [116]. Briefly, DCPD crystals consist of $\mathrm{CaPO}_{4}$ chains arranged parallel to each other, while lattice water molecules are interlayered between them [117]. The atomic structure of the $\{010\}$ interface of DCPD with water was determined [118]. Recently, data on DCPD solubility have been updated by solid titration technique [119]. The optical properties of DCPD were described [120], while many additional data on DCPD including a good drawing of its atomic structure might be found in Ref. [121].

DCPD is of biological importance because it is often found in pathological calcifications (dental calculi, crystalluria, chondrocalcinosis and urinary stones) and some carious lesions [4,64-66]. It was proposed as an intermediate in both bone mineralization and dissolution of enamel in acids (dental erosion) $[4,64,65]$. In medicine, DCPD is used in self-setting calcium orthophosphate formulations [104] and as an intermediate for tooth remineralization. DCPD is added to toothpaste both for caries protection (in this case, it is often coupled with F-containing compounds such as $\mathrm{NaF}$ and/or $\mathrm{Na}_{2} \mathrm{PO}_{3} \mathrm{~F}$ ) and as a gentle polishing agent [107]. Other applications include a flame retardant [122], a slow release fertilizer, using in glass production, as well as calcium supplement in food, feed and cereals. In food industry, it serves as a texturizer, bakery improver and water retention additive. In diary industry, DCPD is used as a mineral supplement. In addition, plate-like crystals of DCPD might be used as a non-toxic, anticorrosive and passivating pigment for some ground coat paints [105]

\section{DCPA (or DCP)}

Dicalcium phosphate anhydrous $\left(\mathrm{CaHPO}_{4}\right.$; the IUPAC name is calcium hydrogen orthophosphate anhydrate; the mineral monetite) is the anhydrous form of DCPD. Although DCPD has been known since, at least, 1804 [1,2], DCPA was differentiated as "mono-hydrogen calcium orthophosphate, $\mathrm{HCaPO}_{4}$ ” by 1879 [107]. As a mineral, monetite was first described in 1882 in rock-phosphate deposits from the Moneta (now Monito) Island (archipelago of Puerto Rico), which contains a notable occurrence [123].

Due to the absence of water inclusions, DCPA is less soluble than DCPD Table 1. Like DCPD, DCPA can be crystallized from aqueous solutions containing $\mathrm{Ca} / \mathrm{P}$ ratio $\sim 1$ at solution $\mathrm{pH}$ within $\sim 2.0<\mathrm{pH}$ $<\sim 6.5$ but at temperatures $>\sim 90{ }^{\circ} \mathrm{C}$. In addition, DCPA might be 
prepared by dehydration of DCPD. Furthermore, it might be also prepared at ambient temperatures in water-restricted or non-aqueous systems, such as gels [113], ethanol [124], as well as in the oil-in-water and water-in-oil systems [125]. DCPA is physically stable and resisted hydration even when dispersed in water for over 7 months in the temperature range of $4-50^{\circ} \mathrm{C}[126]$. A calcium-deficient DCPA was also prepared. It might be sintered at $\sim 300^{\circ} \mathrm{C}$ [127]. Unlike DCPD, DCPA occurs in neither normal nor pathological calcifications. It is used in self-setting calcium orthophosphate formulations [104]. Besides, DCPA might be implanted as bioceramics [128]. Other applications include using as a polishing agent, a source of calcium and phosphate in nutritional supplements (e.g., in prepared breakfast cereals, enriched flour and noodle products), a tabletting aid [129] and a toothpaste component [107]. In addition, it is used as a dough conditioner in food industry [105].

\section{OCP}

Octacalcium phosphate $\left(\mathrm{Ca}_{8}\left(\mathrm{HPO}_{4}\right)_{2}\left(\mathrm{PO}_{4}\right)_{4} \cdot 5 \mathrm{H}_{2} \mathrm{O}\right.$; the IUPAC name is tetracalcium hydrogen orthophosphate diorthophosphate pentahydrate, another name is octacalcium bis(hydrogenphosphate) tetrakis(phosphate) pentahydrate) is often found as an unstable transient intermediate during the precipitation of the thermodynamically more stable calcium orthophosphates (e.g., CDHA) in aqueous solutions. To the best of my findings [1,2], OCP has been known since, at least, 1843, when Percy published a paper [130], in which he described formation of "a new hydrated phosphate of lime" with a chemical formula $2 \mathrm{CaO}+$ $\mathrm{PO} 5+6 \mathrm{HO}$, in which " 1 equiv. water being basic and 5 constitutional". However, according to Bjerrum [131], a calcium orthophosphate with the OCP composition was first described by Berzelius in 1836 .

The preparation techniques of OCP are available in literature [132135]. Briefly, to prepare OCP, Ca- and $\mathrm{PO}_{4}$-containing chemicals must be mixed to get the supersaturated aqueous solutions with the $\mathrm{Ca} / \mathrm{P}$ ratio equal to 1.33 . However, OCP might be non-stoichiometric and be either $\mathrm{Ca}$-deficient $(\mathrm{Ca} / \mathrm{P}=1.26)$ or include excessive calcium (up to $\mathrm{Ca} / \mathrm{P}=1.48$ ) in the structure [135]. Furthermore, a partially hydrolyzed form of $\mathrm{OCP}$ with $\mathrm{Ca} / \mathrm{P}$ molar ratio of 1.37 might be prepared $[135,136]$. The full hydrolysis of OCP into CDHA occurs within $~ 6$ hours [134]. Ion-substituted OCP might be prepared as well $[137,138]$. Crystals of OCP are typically small, extremely platy and almost invariably twinned.

The triclinic structure of OCP displays apatitic layers (with atomic arrangements of calcium and orthophosphate ions similar to those of HA) separated by hydrated layers (with atomic arrangements of calcium and orthophosphate ions similar to those in DCPD) [4-6,135]. A similarity in crystal structure between OCP and HA $[139,140]$ is one reason that the epitaxial growth of these phases is observed. It is generally assumed that, in solutions, the hydrated layer of the (100) face is the layer most likely exposed to solution. The water content of OCP crystals is about $20 \%$ that of DCPD and this is partly responsible for its lower solubility. New data on OCP solubility have been published recently [141].

OCP is of a great biological importance because it is one of the stable components of human dental and urinary calculi $[142,143]$. OCP was first proposed by W. E. Brown to participate as the initial phase in enamel mineral formation and bone formation through subsequent precipitation and stepwise hydrolysis of OCP [139,140,144]. It plays an important role in formation of apatitic biominerals in vivo [145]. A "central OCP inclusion" (also known as "central dark line") is seen by transmission electron microscopy in many biological apatites and in synthetically precipitated CDHA [146-148]. Although OCP has not been observed in vascular calcifications, it has been strongly suggested as a precursor phase to biological apatite found in natural and prosthetic heart valves $[149,150]$. In surgery, OCP is used for implantation into bone defects [151-154]. For the comprehensive information on OCP, the readers are referred to other reviews [135,142].

\section{$\beta$-TCP}

$\beta$-tricalcium phosphate $\left(\beta-\mathrm{Ca}_{3}\left(\mathrm{PO}_{4}\right)_{2}\right.$; the IUPAC name is tricalcium diorthophosphate beta, other names are calcium orthophosphate tribasic beta or tricalcium bis(orthophosphate) beta) is one of the polymorphs of TCP. Although calcium orthophosphates with the composition close to that of TCP, CDHA and HA were known in 1770 -s [1,2], $\alpha$ - and $\beta$ - polymorphs of TCP were differentiated only by $1932[155,156]$.

$\beta$-TCP cannot be precipitated from aqueous solutions. It is a high temperature phase, which can be prepared at temperatures above $800^{\circ} \mathrm{C}$ by thermal decomposition of CDHA or by solid-state interaction of acidic calcium orthophosphates, e.g., DCPA, with a base, e.g., $\mathrm{CaO}$. In all cases, the chemicals must be mixed in the proportions to get the $\mathrm{Ca} / \mathrm{P}$ ratio equal to 1.50 . However, $\beta$-TCP can also be prepared at relatively low temperatures $\left(\sim 150^{\circ} \mathrm{C}\right)$ by precipitation in water-free mediums, such as ethylene glycol $[157,158]$. Apart from the chemical preparation routes, ion-substituted $\beta$-TCP can be prepared by calcining of bones $[159,160]$ : such type of calcium orthophosphates is occasionally called "bone ash" [161]. At temperatures above $\sim 1125^{\circ} \mathrm{C}$, $\beta$-TCP is transformed into a high-temperature phase $\alpha$-TCP. Being the stable phase at room temperature, $\beta$-TCP is less soluble in water than $\alpha$-TCP Table 1 . Both ion-substituted [162-165] and organically modified [166-168] forms of $\beta$-TCP can be synthesized, as well. The modern structural data on $\beta$-TCP are available in Refs [169-171], those on Vicker's and Knoop microhardness studies might be found if Ref [172], while solubility data - in Ref [173]. Furthermore, an ability of $\beta$-TCP to store an electrical charge by electrical polarization was studied and this material was found to have a suitable composition and structure for both ion conduction and charge storage [174].

Pure $\beta$-TCP never occurs in biological calcifications. Only the Mg-substituted form ( $\beta$-TCMP - $\beta$-tricalcium magnesium phosphate, $\beta$ - $\left.(\mathrm{Ca}, \mathrm{Mg})_{3}\left(\mathrm{PO}_{4}\right)_{2}\right)$, which is often called whitlockite to honor $\mathrm{Mr}$. Herbert Percy Whitlock (1868 - 1948), an American mineralogist, the curator of the American Museum of Natural History, New York City, New York, USA [175]. Since $\beta$-TCMP is less soluble than $\beta$-TCP [176], it is formed instead of $\beta$-TCP in dental calculi and urinary stones, dentineal caries, salivary stones, arthritic cartilage, as well as in some soft-tissue deposits [4,64-66,177-180]. However, it has not been observed in enamel, dentine or bone. In medicine, $\beta$-TCP is used in the self-setting calcium orthophosphate formulations [104] and other types of bone grafts $[159,181-185]$. Dental applications of $\beta$-TCP are also known. For example, $\beta$-TCP is added to some brands of toothpaste as a gentle polishing agent [107]. Multivitamin complexes with calcium orthophosphate are widely available in the market and $\beta$-TCP is used as the calcium phosphate there. In addition, $\beta$-TCP serves as a texturizer, bakery improver and anti-clumping agent for dry powdered food (flour, milk powder, dried cream, cocoa powder). Besides, $\beta$-TCP is added as a dietary or mineral supplement to food and feed [186]. Occasionally, $\beta$-TCP might be used as inert filler in pelleted drugs. Other applications comprise porcelains, pottery, enamel, using as a component for mordants and ackey, as well as a polymer stabilizer [105]. $\beta$-TCP of a technical grade (as either calcined natural phosphorites or bone dust) is used as a slow release fertilizer for acidic soils [13]. 


\section{a-TCP}

$\alpha$-tricalcium phosphate $\left(\alpha-\mathrm{Ca}_{3}\left(\mathrm{PO}_{4}\right)_{2}\right.$; the IUPAC name is tricalcium diorthophosphate alpha, other names are calcium orthophosphate tribasic alpha or tricalcium bis(orthophosphate) alpha) is another polymorph of TCP, which was differentiated by 1932 [155,156]. $\alpha$-TCP is also a high temperature phase; therefore, it cannot be precipitated from aqueous solutions either. Thus, $\alpha-\mathrm{TCP}$ is usually prepared by the same techniques as $\beta$-TCP (see the previous section) but, since the $\beta$-TCP $\rightarrow \alpha$-TCP transition temperature is $\sim 1125^{\circ} \mathrm{C}$ [187], calcining is performed at temperatures above $\sim 1200^{\circ} \mathrm{C}$ [188]. Consequently, $\alpha$-TCP is often considered as a high temperature polymorph of $\beta$-TCP. However, data are available that $\alpha$-TCP might be prepared at lower temperatures. Namely, at the turn of the millennium, the previously forgotten data that the presence of silicates stabilized $\alpha$-TCP at temperatures of $800-1000^{\circ} \mathrm{C}$ [189] were rediscovered again. Such type of $\alpha$-TCP is called "silica stabilized a-TCP" [190-192]. Furthermore, sometimes, $\alpha$-TCP might be prepared at even lower temperatures ( $700^{\circ} \mathrm{C}$ ) by a thermal decomposition of low temperature ACPs [193].

Although $\alpha$-TCP and $\beta$-TCP have exactly the same chemical composition, they differ by the crystal structure Table 3 and solubility Table 1. In the absence of humidity, both polymorphs of TCP are stable at room temperatures; however, according to a density functional study, stability of $\beta$-TCP crystal lattice exceeds that of $\alpha$-TCP [170]. Therefore, of them, $\alpha$-TCP is more reactive in aqueous systems, has a higher specific energy and in aqueous solutions it can be hydrolyzed to CDHA [194-196]. Milling was found to increase the $\alpha$-TCP reactivity even more [197]. Although, $\alpha$-TCP never occurs in biological calcifications, in medicine, it is used as a component of self-setting calcium orthophosphate formulations [104]. On the other hand, the chemically pure $\alpha$-TCP has received not much interest in the biomedical field [183]. The disadvantage for using $\alpha$-TCP is its quick resorption rate (faster than formation of a new bone), which limits its application in this area. However, the silicon stabilized $\alpha$-TCP (more precisely as a biphasic composite with $\mathrm{HA}$ ) has been commercialized as a starting material to produce bioresorbable porous ceramic scaffolds to be used as artificial bone grafts [190-192]. Upon implantation, a-TCP tends to convert to CDHA, which drastically reduces further degradation rate. Theoretical insights into bone grafting properties of the silicon-stabilized $\alpha$-TCP might be found in Ref [198]. The structure of $\alpha$-TCP is well described in literature [170,171], while the surface and adsorption properties are available in Ref [199]. Similar to $\beta$-TCP, $\alpha$-TCP of a technical grade might be used slow release fertilizer for acidic soils [105].

To conclude, one should briefly mention on an existence of $\alpha^{\prime}$ TCP polymorph, which was discovered in 1959 [189]. However, this TCP polymorph lacks of any practical interest because it only exists at temperatures between $\sim 1450^{\circ} \mathrm{C}$ and its melting point $\left(\sim 1756^{\circ} \mathrm{C}\right)$. It reverts to $\alpha$-TCP polymorph by cooling below the transition temperature.

\section{ACP}

Amorphous calcium phosphates (ACPs) represent a special class of calcium orthophosphate salts, having variable chemical but rather identical glass-like physical properties, in which there are neither translational nor orientational long-range orders of the atomic positions. To the best of my findings [1,2], ACP was first prepared in 1845 [200]. Nevertheless, until recently [201], ACP has often been considered as an individual calcium orthophosphate with a variable chemical composition, while, in reality, ACP is just an amorphous state of other calcium orthophosphates. Therefore, in principle, all compounds mentioned in Table 1 might be somehow fabricated in an amorphous state but, currently, only few of them (e.g., an amorphous TCP) are known [201]. Thus, strictly speaking, ACP should be excluded from Table 1. Furthermore, since ACPs do not have the definite chemical composition, the IUPAC nomenclature is not applicable to describe them.

Depending on the production temperatures, all types of ACP are divided into two major groups: low-temperature ACPs (prepared in solutions, usually aqueous ones) and high-temperature ACPs [201]. Low-temperature ACPs (described by the chemical formula $\left.\mathrm{Ca}_{x} \mathrm{H}_{y}\left(\mathrm{PO}_{4}\right) \cdot n \mathrm{H}_{2} \mathrm{O}, n=3-4.5 ; 15-20 \% \mathrm{H}_{2} \mathrm{O}\right)$ are often encountered as a transient precursor phase during precipitation of other calcium orthophosphates in aqueous systems. Usually, an ACP is the first phase precipitated from supersaturated solutions (the higher supersaturation, the better) prepared by rapid mixing of solutions containing ions of calcium and orthophosphate $[5,201]$. Such ACP precipitates usually look like spherical particles with diameters in the range 200 to 1200 $\AA$ without a definite structure. Generally, the ACP particles are smaller if prepared under conditions of high supersaturation and/ or high $\mathrm{pH}$, while for a given $\mathrm{pH}$, higher temperatures give larger particles [202,203]. The freshly precipitated ACPs contain $10-20 \%$ by weight of tightly bound water, which is removed by vacuum drying at elevated temperature [204]. The amorphization degree of ACPs increases with the concentration increasing of $\mathrm{Ca}$ - and $\mathrm{PO}_{4}$-containing solutions, as well as at a high solution $\mathrm{pH}$ and a low crystallization temperature. A continuous gentle agitation of as precipitated ACPs in the mother solution, especially at elevated temperatures, results in a slow recrystallization and formation of better crystalline calcium orthophosphates, such as CDHA [4,5]. In addition, other production techniques of ACPs are known [201].

The lifetime of ACPs in aqueous solutions was reported to be a function of the presence of additive molecules and ions, $\mathrm{pH}$, ionic strength and temperature. Thus, ACPs may persist for appreciable periods and retain the amporphous state under some specific experimental conditions [203]. The chemical composition of ACPs strongly depends on the solution $\mathrm{pH}$ and the concentrations of mixing solutions. For example, ACPs with $\mathrm{Ca} / \mathrm{P}$ ratios in the range of 1.18 (precipitated at solution $\mathrm{pH}=6.6$ ) to 1.53 (precipitated at solution $\mathrm{pH}=$ 11.7) $[5,205]$ and even to $2.5[4,64,65]$ were described. It should be noted that unsubstituted ACPs are unstable in aqueous solutions and even when stored dry they tend to transform into more crystalline calcium orthophosphates, such as poorly crystalline CDHA. The presence of poly(ethylene glycol) [206], ions of pyrophosphate, carbonate and/or magnesium in solutions during the crystallization promotes formation of ACPs and slows down their further transformation, while the presence of fluoride has the opposite effect $[4-6,81,207]$. In general, low temperatures ACPs heated to $\sim 550^{\circ} \mathrm{C}$ (so that all volatiles have already escaped) remain amorphous, but further heating above $\sim 650^{\circ} \mathrm{C}$ causes their transformation into crystalline calcium orthophosphates, such as $\alpha$ - or $\beta$-TCP, HA, mixtures thereof, depending on the $\mathrm{Ca} / \mathrm{P}$ ratio of the ACP heated.

High-temperature ACPs might be prepared using high energy processing at elevated temperatures [201]. This method is based on a rapid quenching of melted calcium orthophosphates occurring, e.g., during plasma spraying of HA $[87,208,209]$. A plasma jet, possessing very high temperatures $\left(\sim 5000-\sim 20000^{\circ} \mathrm{C}\right)$, partly decomposes HA. That results in formation of a complicated mixture of products, some of which would be ACPs. Obviously, all types of high-temperature 
Citation: Dorozhkin SV (2014) Calcium Orthophosphates: Occurrence, Properties and Major Applications. Bioceram Dev Appl 4: 081. doi: 10.4172/2090-5025.1000081

Page 8 of 20

\begin{tabular}{|c|c|c|c|c|}
\hline Compound & Space group & Unit cell parameters & $Z^{\text {[a] }}$ & $\begin{array}{l}\text { Density, } \\
\mathrm{g} \mathrm{cm}^{-3}\end{array}$ \\
\hline MCPM & triclinic $P \overline{1}$ & $\begin{array}{l}a=5.6261(5), b=11.889(2), c=6.4731(8) \AA \\
\alpha=98.633(6)^{\circ}, \beta=118.262(6)^{\circ}, \gamma=83.344(6)^{\circ}\end{array}$ & 2 & 2.23 \\
\hline MCPA & triclinic $P \overline{1}$ & $\begin{array}{l}a=7.5577(5), b=8.2531(6), c=5.5504(3) \AA \\
\alpha=109.87(1)^{\circ}, \beta=93.68(1)^{\circ}, y=109.15(1)^{\circ}\end{array}$ & 2 & 2.58 \\
\hline DCPD & monoclinic la & $a=5.812(2), b=15.180(3), c=6.239(2) \AA, \beta=116.42(3)^{\circ}$ & 4 & 2.32 \\
\hline DCPA & triclinic $P \overline{1}$ & $\begin{array}{l}a=6.910(1), b=6.627(2), c=6.998(2) \AA \\
\alpha=96.34(2)^{\circ}, \beta=103.82(2)^{\circ}, y=88.33(2)^{\circ}\end{array}$ & 4 & 2.89 \\
\hline OCP & triclinic $P \overline{1}$ & $\begin{array}{l}a=19.692(4), b=9.523(2), c=6.835(2) \AA, \alpha=90.15(2)^{\circ}, \beta=92.54(2)^{\circ}, \gamma= \\
108.65(1)^{\circ}\end{array}$ & 1 & 2.61 \\
\hline$\alpha-\mathrm{TCP}$ & monoclinic $P 2_{1} / a$ & $a=12.887(2), b=27.280(4), c=15.219(2) \AA, \beta=126.20(1)^{\circ}$ & 24 & 2.86 \\
\hline$\beta-\mathrm{TCP}$ & rhombohedral $\mathrm{R} 3 \mathrm{cH}$ & $a=b=10.4183(5), c=37.3464(23) \AA, y=120^{\circ}$ & $21^{[b]}$ & 3.08 \\
\hline HA & $\begin{array}{l}\text { monoclinic } P 2_{1} / \mathrm{b} \\
\text { or hexagonal } P 6_{3} / \mathrm{m}\end{array}$ & $\begin{array}{l}a=9.84214(8), b=2 a, c=6.8814(7) \AA, y=120^{\circ} \text { (monoclinic) } \\
a=b=9.4302(5), c=6.8911(2) \AA, y=120^{\circ} \text { (hexagonal) }\end{array}$ & $\begin{array}{l}4 \\
2\end{array}$ & 3.16 \\
\hline FA & hexagonal $P 6_{3} / \mathrm{m}$ & $a=b=9.367, c=6.884 \AA, y=120^{\circ}$ & 2 & 3.20 \\
\hline OA & hexagonal $P \overline{6}$ & $a=b=9.432, c=6.881 \AA, \alpha=90.3^{\circ}, \beta=90.0^{\circ}, y=119.9^{\circ}$ & 1 & $\sim 3.2$ \\
\hline TTCP & monoclinic $P 2_{1}$ & $a=7.023(1), b=11.986(4), c=9.473(2) \AA, \beta=90.90(1)^{\circ}$ & 4 & 3.05 \\
\hline
\end{tabular}

[a] Number of formula units per unit cell.

${ }^{[b]}$ Per the hexagonal unit cell.

Table 3: Crystallographic data of calcium orthophosphates $[5,88,89]$.

ACPs are definitively anhydrous contrary to the precipitated ACPs. Unfortunately, no adequate chemical formula is available to describe the high-temperature ACPs.

In general, as all amorphous compounds are characterized by a lack of long-range order, it is problematic to discuss the structure of ACPs (they are X-ray amorphous). Concerning a short-range order (SRO) in ACPs, it exists, just due to the nature of chemical bonds. Unfortunately, in many cases, the SRO in ACPs is uncertain either, because it depends on many variables, such as $\mathrm{Ca} / \mathrm{P}$ ratio, preparation conditions, storage, admixtures, etc. Infrared spectra of ACPs show broad featureless phosphate absorption bands. Electron microscopy of freshly precipitated ACPs usually shows featureless nearly spherical particles with diameters in the range of 20 to $200 \mathrm{~nm}$. However, there is a questionable opinion that ACPs might have an apatitic structure but with a crystal size so small, that they are X-ray amorphous. This is supported by X-ray absorption spectroscopic data (EXAFS) on biogenic and synthetic samples [210-213]. On the other hand, it was proposed that the basic structural unit of the precipitated ACPs is a $9.5 \AA$ diameter, roughly spherical cluster of ions with the composition of $\mathrm{Ca}_{9}\left(\mathrm{PO}_{4}\right)_{6}$ Figure 7 [5,205,214,215]. These clusters were found experimentally as first nuclei during the crystallization of CDHA and a model was developed to describe the crystallization of HA as a stepwise assembly of these units [216] (see section 5.10. HA (or HAp, or OHAp) below). Biologically, ion-substituted ACPs (always containing ions of $\mathrm{Na}, \mathrm{Mg}$, carbonate and pyrophosphate) are found in soft-tissue pathological calcifications (e.g., heart valve calcifications of uremic patients) [4,64-66].

In medicine, ACPs are used in self-setting calcium orthophosphate formulations [104]. Bioactive composites of ACPs with polymers have properties suitable for use in dentistry [107,201] and surgery [201,217]. Due to a reasonable solubility and physiological $\mathrm{pH}$ of aqueous solutions, ACPs appeared to be consumable by some microorganisms and, due to this reason, it might be added as a mineral supplement to culture media. Non-biomedical applications of ACPs comprise their using as a component for mordants and ackey. In food industry, ACPs are used for syrup clearing. Occasionally, they might be used as inert filler in pelleted drugs. In addition, ACPs are used in glass and pottery production and as a raw material for production of some organic phosphates. To get further details on ACPs, the readers are referred to special reviews [201,215,218].

\section{CDHA (or Ca-def HA)}

Calcium-deficient hydroxyapatite $\left(\mathrm{Ca}_{10-x}\left(\mathrm{HPO}_{4}\right)_{x}\left(\mathrm{PO}_{4}\right)_{6-x}(\mathrm{OH})_{2-x}(0\right.$ $<x<1)$ ) became known since the earliest experiments on establishing the chemical composition of bones performed in 1770-s [1,2]. However, the initial appropriate term "subphosphate of lime" appeared by 1819 [219]. Other chemical formulae such as $\mathrm{Ca}_{10-x}\left(\mathrm{HPO}_{4}\right)_{2 x}\left(\mathrm{PO}_{4}\right)_{6-2 x}(\mathrm{OH})_{2}$ $(0<x<2), \mathrm{Ca}_{10-x-y}\left(\mathrm{HPO}_{4}\right)_{x}\left(\mathrm{PO}_{4}\right)_{6-x}(\mathrm{OH})_{2-x-2 y}(0<x<2$ and $y<x / 2)$, $\mathrm{Ca}_{10-x}\left(\mathrm{HPO}_{4}\right)_{x}\left(\mathrm{PO}_{4}\right)_{6-x}(\mathrm{OH})_{2-x}\left(\mathrm{H}_{2} \mathrm{O}\right)_{x}(0<x<1), \mathrm{Ca}_{9-x}\left(\mathrm{HPO}_{4}\right)_{1+2 x}\left(\mathrm{PO}_{4}\right)_{5}$ ${ }_{2 x}(\mathrm{OH})$, etc. were also proposed to describe its variable composition [5]. As seen from these formulae, Ca-deficiency is always coupled with both $\mathrm{OH}$-deficiency and protonation of some $\mathrm{PO}_{4}$ groups with simultaneous formation of the ionic vacancies in the crystal structure [220]. In addition, CDHA often contains tightly bound water molecules, which might occupy some of these ionic vacancies. For example, there is an approach describing a lack of the hydroxide vacancies in CDHA: to

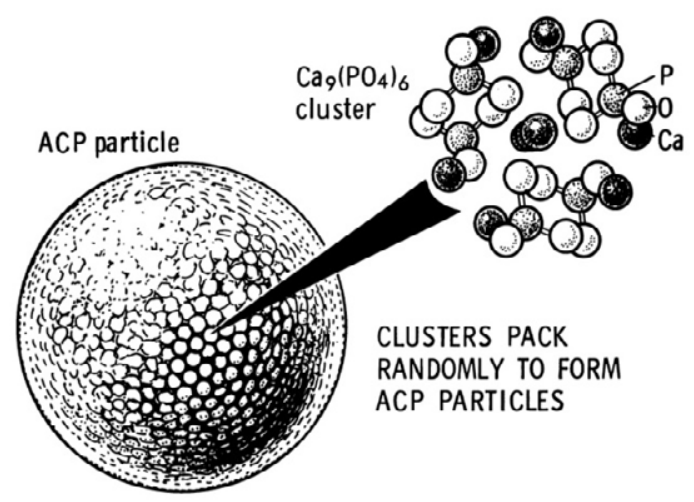

Figure 7: A model of ACP structure. Reprinted from Ref. [214] with permission. 
perform the necessary charge compensation of the missing $\mathrm{Ca}^{2+}$ ions, a portion of $\mathrm{OH}^{-}$anions is substituted by neutral water molecules [221]. This water is removed by vacuum drying at elevated temperature. Concerning possible vacancies of orthophosphate ions, nothing is known about their presence in CDHA. It is just considered that a portion of $\mathrm{PO}_{4}^{3-}$ ions is either protonated ( $2 \mathrm{HPO}_{4}^{2-}$ ) or substituted by other ions (e.g., $\mathrm{CO}_{3}^{2-}$ ) [222]. Since $\mathrm{CDHA}$ does not have any definite chemical composition, the IUPAC nomenclature is not applicable to describe it.

CDHA can be easily prepared by simultaneous addition of Ca- and $\mathrm{PO}_{4}$-containing solutions in the proportions to get $\mathrm{Ca} / \mathrm{P}$ ratio within 1.50 -1.67 into boiling water followed by boiling the suspension for several hours (an ageing stage). That is why, in literature it might be called as "precipitated HA (PHA)" [223,224]. Besides, it might be prepared by hydrolysis of $\alpha$-TCP [194-196]. Other preparation techniques of CDHA are known as well [225-228]. During ageing, initially precipitated ACPa are restructured and transformed into CDHA. Therefore, there are many similarities in the structure, properties and application between the precipitated in alkaline solutions $(\mathrm{pH}>8)$ ACPs and CDHA. Some data indicated on a presence of intermediate phases during further hydrolysis of CDHA to a more stable HA-like phase [229]. In general, CDHA crystals are poorly crystalline and of submicron dimensions. They have a very large specific surface area, typically $25-100 \mathrm{~m}^{2} / \mathrm{g}$. On heating above $\sim 700^{\circ} \mathrm{C}, \mathrm{CDHA}$ with $\mathrm{Ca} / \mathrm{P}=1.5$ converts to $\beta$ - TCP and that with $1.5<\mathrm{Ca} / \mathrm{P}<1.67$ converts into a biphasic composite of HA and $\beta$-TCP (see section 5.14. Biphasic, triphasic and multiphasic calcium orthophosphate formulations below) [230]. A solid-state transformation mechanism of CDHA into $\mathrm{HA}+\beta$-TCP biocomposite was proposed [231,232].

The variability in $\mathrm{Ca} / \mathrm{P}$ molar ratio of $\mathrm{CDHA}$ has been explained through different models: surface adsorption, lattice substitution and intercrystalline mixtures of HA and OCP [233]. Due to a lack of stoichiometry, CDHA is usually doped by other ions [63]. The doping extent depends on the counter-ions of the chemicals used for CDHA preparation. Direct determinations of the CDHA structures are still missing and the unit cell parameters remain uncertain. However, unlike that in ACPs (see section 3.8. ACP above), a long-range order exists in CDHA. Namely, the following lattice parameters were reported for CDHA with $\mathrm{Ca} / \mathrm{P}=1.5: a=9.4418(20) \AA$ and $c=6.8745(17) \AA$ [228].

A systematic study of defect constellations in CDHA is available in literature [221]. As a first approximation, CDHA may be considered as HA with some ions missing (ionic vacancies) [234]. The more amount of $\mathrm{Ca}$ is deficient, the more disorder, imperfections and vacancies are in the CDHA structure [235]. Furthermore, a direct correlation between the Ca-deficiency and the mechanical properties of the crystals was found: calcium deficiency lead to an $80 \%$ reduction in the hardness and elastic modulus and at least a $75 \%$ reduction in toughness in plate-shaped HA crystals [236]. Theoretical investigations of the defect formation mechanism relevant to non-stoichiometry in CDHA are available elsewhere [237].

Unsubstituted CDHA (i.e., that containing ions of $\mathrm{Ca}^{2+}, \mathrm{PO}_{4}^{3-}$, $\mathrm{HPO}_{4}^{2-}$ and $\mathrm{OH}^{-}$only) does not exist in biological systems. However, the ion substituted CDHA: $\mathrm{Na}^{+}, \mathrm{K}^{+}, \mathrm{Mg}^{2+}, \mathrm{Sr}^{2+}$ for $\mathrm{Ca}^{2+} ; \mathrm{CO}_{3}^{2-}$ for $\mathrm{PO}_{4}^{3-}$ or $\mathrm{HPO}_{4}^{2-} ; \mathrm{F}^{-}, \mathrm{Cl}^{-}, \mathrm{CO}_{3}{ }^{2-}$ for $\mathrm{OH}^{-}$, plus some water forms biological apatite - the main inorganic part of animal and human normal and pathological calcifications $[4,63,64]$. Therefore, CDHA is a very promising compound for industrial manufacturing of artificial bone substitutes [238], including drug delivery applications [239]. Nonbiomedical applications of CDHA are similar to those of ACP and HA.
Interestingly that CDHA was found to possess a catalytic activity to produce biogasoline [240].

\section{HA (or HAp, or OHAp)}

Hydroxyapatite $\left(\mathrm{Ca}_{5}\left(\mathrm{PO}_{4}\right)_{3}(\mathrm{OH})\right.$, but is usually written as $\mathrm{Ca}_{10}\left(\mathrm{PO}_{4}\right)_{6}(\mathrm{OH})_{2}$ to denote that the crystal unit cell comprises two molecules; the IUPAC name is pentacalcium hydroxide tris(orthophosphate)) is the second most stable and least soluble calcium orthophosphate after FA. Apatites were recognized as calcium phosphates by, at least, 1789 [1,2]. Here, it is worth noting that hydroxylapatite would be a more accurate abbreviation expansion of HA (perhaps, hydroxideapatite would be even better because it relates to calcium hydroxide) while by both the medical and material communities HA is usually expanded as hydroxyapatite.

Chemically pure HA crystallizes in the monoclinic space group $P 2_{1} / \mathrm{b}$ [241]. However, at temperatures above $\sim 250^{\circ} \mathrm{C}$, there is a monoclinic to hexagonal phase transition in HA (space group $P 6_{3} / \mathrm{m}$ ) $[5,89,205,242,243]$. The detailed description of the HA structure was first reported in 1964 [244] and its interpretation in terms of aggregation of $\mathrm{Ca}_{9}\left(\mathrm{PO}_{4}\right)_{6}$ clusters, the so-called Posner's clusters, has been widely used since publication of the article by Posner and Betts [204]. In hexagonal HA, the hydroxide ions are more disordered within each row, when compared with the monoclinic form, pointing either upward or downward in the structure. This induces strains that are compensated for by substitutions or ion vacancies. Some impurities, like partial substitution of hydroxide by fluoride or chloride, stabilize the hexagonal structure of HA at ambient temperature. Due to this reason, hexagonal HA is seldom the stoichiometric phase and very rare single crystals of natural HA always exhibit the hexagonal space group. The crystal structure of HA is well described elsewhere $[5,88,89]$, the detailed analysis of the electronic structure, bonding, charge transfer, optical and elastic properties are also available [245-248], while the readers interested in Posner's clusters are referred to other papers [249-251]. A shell model was developed to study the lattice dynamics of HA [252], while a cluster growth model was created to illustrate its growth [216]. Polarization characteristics [253,254] and pyroelectrical properties [255] of HA bioceramics have been investigated. Firstprinciples calculations for the elastic properties of doped HA [256] and vacancy formation in HA [257] were performed. Computer simulations of the structures and properties of HA are well described in feature articles $[258,259]$.

Several techniques might be utilized for HA preparation; they can be divided into solid-state reactions and wet methods [260], which include precipitation, hydrothermal synthesis and hydrolysis of other calcium orthophosphates. However, in all cases, $\mathrm{Ca}$ - and $\mathrm{PO}_{4}$ containing chemicals must be mixed to get the $\mathrm{Ca} / \mathrm{P}$ ratio strictly equal to 1.67. Nevertheless, even under the ideal stoichiometric conditions, the precipitates are generally non-stoichiometric, suggesting intermediate formation of precursor phases, such as ACP and CDHA. Usually unsintered HA is poorly crystalline and often non-stoichiometric, resembling the aforementioned CDHA. However, well crystalline HA can be prepared from an aqueous solution [261]. $\mathrm{HA}$ with the $\mathrm{Ca} / \mathrm{P}$ ratio $>1.67$ (Ca-rich $\mathrm{HA}$ ) might be prepared as well [262]. The detailed information on HA synthesis is available elsewhere [263-267]. In addition, there are good reviews on HA solubility, crystal growth and intermediate phases of HA crystallization [268], as well as on HA dissolution [269].

Pure HA never occurs in biological systems. However, due to the chemical similarities to bone and teeth mineral Table 2, HA is widely 
used as coatings on orthopedic (e.g., hip joint prosthesis) and dental implants [107,270-274]. HA bioceramics is very popular as well [275277]. Due to a great similarity to biological apatite, over a long time HA has been used in liquid chromatography of nucleic acids, proteins and other biological compounds [278-282] and for drug delivery purposes [283-287]. Also, HA is added to some brands of toothpaste as a gentle polishing agent instead of calcium carbonate [288,289]. Nonbiomedical applications of HA include its using as an environmentally friendly filler for elastomers [290], a sorbent of poisonous chemical elements [291,292] and a carrier for various catalysts [293-295]. Furthermore, HA by itself might act as a catalyst for formaldehyde combustion at room temperature [296].

\section{FA (or FAp)}

Fluorapatite $\left(\mathrm{Ca}_{5}\left(\mathrm{PO}_{4}\right)_{3} \mathrm{~F}\right.$, but is usually written as $\mathrm{Ca}_{10}\left(\mathrm{PO}_{4}\right)_{6} \mathrm{~F}_{2}$ to denote that the crystal unit cell comprises two molecules; the IUPAC name is pentacalcium fluoride tris(orthophosphate)) is the only ionsubstituted calcium orthophosphate, considered in this review. Since the presence of $2.5 \%$ of fluorides in natural apatites was established by 1798 [297], this date might be accepted as the earliest hearing of FA.

FA is the hardest (5 according to the Mohs' scale of mineral hardness), most stable and least soluble compound among all calcium orthophosphates Table 1. Perhaps, such "extreme" properties of FA are related to the specific position of $\mathrm{F}^{-}$ions in the center of $\mathrm{Ca}(2)$ triangles of the crystal structure [5,88]. Due to its properties, FA is the only calcium orthophosphate that naturally forms large deposits suitable for the commercial use [12-14] (see also Figure 2. Preparation techniques of the chemically pure FA are similar to the aforementioned ones for HA but the synthesis must be performed in presence of the necessary amount of $\mathrm{F}^{-}$ions (usually, $\mathrm{NaF}$ or $\mathrm{NH}_{4} \mathrm{~F}$ is added). Under some special crystallization conditions (e.g., in presence of gelatin or citric acid), FA might form unusual dumbbell-like fractal morphology that finally are closed to spheres Figure 8 [298,299]. In addition, FA is the only calcium orthophosphate, which melts without decomposition (the melting point is $\sim 1650^{\circ} \mathrm{C}$ ); therefore, big (up to $30 \mathrm{~cm}$ long and, for shorter lengths, up to $1.9 \mathrm{~cm}$ wide) single FA crystals might be grown from FA melts [300,301]. Similar to that for HA (see CDHA), an existence of $\mathrm{CaF}_{2}$-deficient $\mathrm{FA}$ was also detected but for the crystals grown from the FA melt only $[300,302]$. In addition, $\mathrm{FA}$ with an excess of $\mathrm{CaF}_{2}$ was prepared [303]. A hierarchical structure for FA was proposed [304]. The crystal structure of FA for the first time was studied in $1930[305,306]$ and is well described elsewhere $[5,88,89]$. The detailed analysis of the electronic structure, bonding, charge transfer and optical properties is available as well [246]. In addition, there are reviews on FA solubility [268] and the dissolution mechanism [269].

FA easily forms solid solutions with HA with any desired F/OH molar ratio. Such compounds are called fluorhydroxyapatites (FHA) [307-309] or hydroxyfluorapatites (HFA) [310,311] and described with a chemical formula $\mathrm{Ca}_{10}\left(\mathrm{PO}_{4}\right)_{6}(\mathrm{OH})_{2-x} \mathrm{~F}_{x^{\prime}}$, where $0<x<2$. If the $\mathrm{F} / \mathrm{OH}$ ratio is either uncertain or not important, the chemical formula of FHA and HFA is often written as $\mathrm{Ca}_{10}\left(\mathrm{PO}_{4}\right)_{6}(\mathrm{~F}, \mathrm{OH})_{2}$. The lattice parameters, crystal structure, solubility and other properties of FHA and HFA lay in between of those for the chemically pure FA and HA. Namely, the substitution of $\mathrm{F}$ for $\mathrm{OH}$ results in a contraction in the $a$-axis with no significant change in the $c$-axis dimensions and greater resolution of the IR absorption spectra.

Similar to pure HA, pure FA never occurs in biological systems. Obviously, a lack of the necessary amount of toxic fluorides (the acute toxic dose of fluoride is $\sim 5 \mathrm{mg} / \mathrm{kg}$ of body weight) in living organisms is the main reason of this fact (pure FA contains $3.7 \%$ mass. F). Enameloid of shark teeth [11,81,312-316] and some exoskeletons of mollusks [317] seem to be the only exclusions because they contain substantial amounts of fluoride, with is presented there as ionsubstituted, non-stoichiometric FHA or HFA. Among all normal calcified tissues of humans, the highest concentration of fluorides is found in dentine and cementum, while the lowest - in dental enamel Table 2. Nevertheless, one should stress that the amount of fluorides on the very surface of dental enamel might be subtantially increased by using fluoride-containing toothpastes and mouthwashes $[318,319]$. However, in no case, the total amount of fluorides is enough to form FA.

Contrary to the initial expectations [320], chemically pure FA is not used for grafting purposes. Presumably, this is due to the lowest solubility, good chemical stability of FA and toxicity of high amounts of fluorides. However, attempts to test FA-containing formulations [321325], ion-substituted FA [326,327], FHA [328,329] and porous FA bioceramics [330] are kept performing. The effect of fluoride contents in FHA on both osteoblast behavior [331,332] and leukemia cells proliferation [333] has been described. Non-biomedical applications of FA include fluorescent light tubes [334], laser materials [335,336] (in both cases dopants are necessary), as well as catalysts [337].

\section{OA (or OAp, or OXA)}

Oxyapatite $\left(\mathrm{Ca}_{10}\left(\mathrm{PO}_{4}\right)_{6} \mathrm{O}\right.$; the IUPAC name is decacalcium oxide hexakis(phosphate), mineral voelckerite) is the least stable and, therefore, the least known calcium orthophosphate, which, probably, does not exist at all. Nevertheless, a name "voelckerite" was introduced in 1912 by A.F. Rogers (1887 - 1957) for a hypothetical mineral with the chemical composition of $3 \mathrm{Ca}_{3}\left(\mathrm{PO}_{4}\right)_{2}+\mathrm{CaO}[338,339]$, to honor an English agricultural chemist John Christopher Augustus Voelcker (1822 - 1884), who, in 1883, first showed an apparent halogen deficiency in some natural apatites [340]. Therefore, 1883 might be accepted as the earliest hearing of OA.

To the best of my findings, pure OA has never been prepared; therefore, its properties are not well established. Furthermore, still there are serious doubts that pure OA can exist. However, a mixture (or a solid solution?) of OA and HA (oxy-HA) might be prepared by a partial dehydroxylation of $\mathrm{HA}$ at temperatures exceeding $\sim 900^{\circ} \mathrm{C}$ (e.g., during plasma-spray of HA) only in the absence of water vapor [341-345]. It also might be crystallized in glass-ceramics [346]. OA is

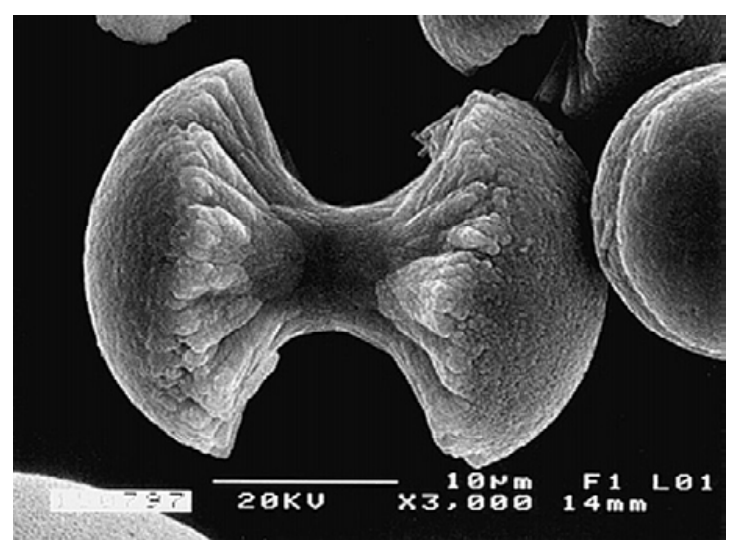

Figure 8: A biomimetically grown aggregate of FA that was crystallized in a gelatin matrix. Its shape can be explained and simulated by a fractal growth mechanism. Scale bar: $10 \mu \mathrm{m}$. Reprinted from Ref. [298] with permission. 
very unstable and has no stability field in aqueous conditions [347]. Namely, data are available, that oxy-HA containing less than $25 \% \mathrm{HA}$ (i.e., almost $\mathrm{OA}$ ) during further dehydration decomposes to a mixture of $\alpha$-TCP and TTCP. In addition, OA is very reactive and transforms to $\mathrm{HA}$ in contact with water vapor [341]. Computer modeling techniques have been employed to qualitatively and quantitatively investigate the dehydration of HA to OA [348]. OA has the hexagonal space group symmetry $P 6$ (174) of cesanite type [88], while the space group symmetry for partially dehydrated HA was found to change from hexagonal $\mathrm{P} 63 / \mathrm{m}$ to triclinic $P 1$ when more than $c a .35 \%$ of the structurally bound water had been removed [343]. On the $c$-axis, pure $\mathrm{OA}$ should have a divalent ion $\mathrm{O}^{2-}$ coupled with a vacancy instead of two neighboring monovalent $\mathrm{OH}^{-}$ions.

Due to the aforementioned problems with OA preparation, it cannot be found in biological systems. In addition, no information on the biomedical applications of OA is available either. Plasma-sprayed coatings of calcium orthophosphates, in which OA might be present as an admixture phase, seem to be the only exception [274].

\section{TTCP (or TetCP)}

Tetracalcium phosphate or tetracalcium diorthophosphate monoxide $\left(\mathrm{Ca}_{4}\left(\mathrm{PO}_{4}\right)_{2} \mathrm{O}\right.$; the IUPAC name is tetracalcium oxide bis(orthophosphate); the mineral hilgenstockite) is the most basic calcium orthophosphate, however, its solubility in water is higher than that of HA Table 1. TTCP has been known since 1883 [349], while the mineral hilgenstockite was named to honor a German metallurgist Gustav Hilgenstock (1844 - 1913), who first discovered it in Thomas slag from blast furnaces [349,350]. Its major industrial importance stems from the fact that it is formed by the reactions between orthophosphates and lime in the manufacture of iron, and through these reactions, TTCP has a significant role in controlling the properties of the metal.

TTCP cannot be precipitated from aqueous solutions. It can be prepared only under the anhydrous conditions by solid-state reactions at temperatures above $\sim 1300^{\circ} \mathrm{C}$, e.g., by heating homogenized equimolar quantities of DCPA and $\mathrm{CaCO}_{3}$ in dry air, or in a flow of dry nitrogen $[5,205,351]$. These reactions should be carried out in a dry atmosphere, in vacuum or with rapid cooling (to prevent uptake of water and formation of HA). Easily DCPA might be replaced by ammonium orthophosphates [352,353], while calcium carbonate might be replaced by calcium acetate [353]; however, in all cases, $\mathrm{Ca} / \mathrm{P}$ ratio must be equal to 2.00. Furthermore, TTCP often appears as an unwanted byproduct in plasma-sprayed HA coatings, where it is formed as a result of the thermal decomposition of $\mathrm{HA}$ to a mixture of high-temperature phases of $\alpha$-TCP, TTCP and $\mathrm{CaO}$ [354]. TTCP is metastable: in both wet environment and aqueous solutions it slowly hydrolyses to HA and calcium hydroxide $[5,205,355]$. Consequently, TTCP is never found in biological calcifications. In medicine, TTCP is widely used for preparation of various self-setting calcium orthophosphate formulations [104,354]; however, to the best of my knowledge, there is no commercial bone-substituting product consisting solely of TTCP. For the comprehensive information on TTCP, the readers are referred to a special review [354], while the spectra [356] and solubility [173] of TTCP are well described elsewhere.

To conclude the description of the individual calcium orthophosphates, one should mention on an interesting opinion $[89,142]$, that all calcium orthophosphates listed in Table 1 might be classified into three major structural types. They comprise: (i) the apatite type, $\mathrm{Ca}_{10}\left(\mathrm{PO}_{4}\right)_{6} \mathrm{X}_{2}$, which includes $\mathrm{HA}, \mathrm{FA}, \mathrm{OA}, \mathrm{CDHA}, \mathrm{OCP}$ and TTCP; (ii) the glaserite type, named after the mineral glaserite, $\mathrm{K}_{3} \mathrm{Na}\left(\mathrm{SO}_{4}\right)_{2}$, which includes all polymorphs of TCP and, perhaps, ACP; (iii) the $\mathrm{Ca}-\mathrm{PO}_{4}$ sheet-containing compounds, which include DCPD, DCPA, MCPM and MCPA. According to the authors, a closer examination of the structures revealed that all available calcium orthophosphates could be included into distorted glaserite type structures, but with varying degrees of distortion $[89,142]$.

\section{Biphasic, triphasic and multiphasic calcium orthophosphate formulations}

Calcium orthophosphates might form biphasic, triphasic and multiphasic (polyphasic) formulations, in which the individual components cannot be separated from each other. Presumably, the individual phases of such compositions are homogeneously "mixed" at a far submicron level $(<0.1 \mu \mathrm{m})$ and strongly integrated with each other. Nevertheless, the presence of all individual phases is easily seen by X-ray diffraction technique [230].

The usual way to prepare multiphasic formulations consists of sintering non-stoichiometric compounds, such as ACP and CDHA, at temperatures above $\sim 700^{\circ} \mathrm{C}$. Furthermore, a thermal decomposition of the stoichiometric calcium orthophosphates at temperatures above $\sim 1300^{\circ} \mathrm{C}$ might be used as well; however, this approach often results in formation of complicated mixtures of various products including admixtures of $\mathrm{CaO}$, calcium pyrophosphates, etc. [230]. Namely, transformation of HA into polyphasic calcium orthophosphates by annealing in a vacuum occurs as this: the outer part of HA is transformed into $\alpha$-TCP and TTCP, while the $\alpha$-TCP phase of the surface further transforms into $\mathrm{CaO}$. Besides, in the boundary phase, HA is transformed into TTCP [357].

Historically, Nery and Lynch with co-workers first used the term biphasic calcium phosphate (BCP) in 1986 to describe a bioceramic, that consisted of a mixture of HA and $\beta$-TCP [358]. Based on the results of X-ray diffraction analysis, these authors found that the "tricalcium phosphate" preparation material used in their early publication [359] was in fact a mixture of 20\% HA and $~ 80 \%$ $\beta$-TCP. Currently, only biphasic and triphasic calcium orthophosphate formulations are known; perhaps, more complicated formulations will be manufactured in future. Furthermore, nowadays, multiphasic and/ or polyphasic compositions consisting of high-temperature phases of calcium orthophosphates, such as $\alpha$-TCP, $\beta$-TCP, HA and, perhaps, high-temperature ACP, OA and TTCP, are known only. No precise information on multiphasic compositions, containing MCPM, MCPA, DCPD, DCPA, low-temperature ACP, OCP and CDHA has been found in literature [230]. Perhaps, such formulations will be produced in future.

All BCP formulations might be subdivided into two major groups: those consisting of calcium orthophosphates having either the same (e.g., $\alpha$-TCP and $\beta$-TCP) or different (e.g., $\beta$-TCP and HA) molar $\mathrm{Ca} / \mathrm{P}$ ratios. Among all known $\mathrm{BCP}$ formulations, $\mathrm{BCP}$ consisting of $\mathrm{HA}$ and $\beta$-TCP is both the most known and the best investigated [230]. In 1986, LeGeros in USA and Daculsi in France initiated the basic studies on preparation of this type of BCP and its in vitro properties. This material is soluble and gradually dissolves in the body, seeding new bone formation as it releases calcium and orthophosphate ions into the biological medium. Presently, commercial BCP products of different or similar HA $/ \beta$-TCP ratios are manufactured in many parts of the world as bone-graft or bone substitute materials for orthopaedic and dental applications under various trademarks and several manufacturers [230]. A similar combination of $\alpha$-TCP with HA forms BCP as well 
Citation: Dorozhkin SV (2014) Calcium Orthophosphates: Occurrence, Properties and Major Applications. Bioceram Dev Appl 4: 081. doi: 10.4172/2090-5025.1000081

Page 12 of 20

\section{[191,360-362].}

Recently the concept of BCP has been extended by preparation and characterization of biphasic TCP (BTCP), consisting of $\alpha$-TCP and $\beta$-TCP phases [363-365]. It is usually prepared by heating ACP precursors [363-365], in which the $\alpha-\mathrm{TCP} / \beta-\mathrm{TCP}$ ratio can be controlled by aging time and $\mathrm{pH}$ value during synthesis of the amorphous precursor [364]. Furthermore, triphasic formulations, consisting of HA, $\alpha$-TCP and $\beta$-TCP [366] or HA, $\alpha$-TCP and TTCP [357] have been prepared [230].

It is important to recognize, that the major biomedical properties (such as bioactivity, bioresorbability, osteoconductivity and osteoinductivity) of the multiphasic formulations might be adjusted by changing the ratios among the phases. When compared to both $\alpha$ - and $\beta$-TCP, HA is a more stable phase under the physiological conditions, as it has a lower solubility (Table 1) and, thus, slower resorption kinetics. Therefore, due to a higher biodegradability of the $\alpha$ - or $\beta$-TCP component, the reactivity of BCP increases with the TCP/HA ratio increasing. Thus, in vivo bioresorbability of BCP can be adjusted through the phase composition. Similar conclusions are also valid for both the biphasic TCP (in which $\alpha$-TCP is a more soluble phase) and the triphasic (HA, $\alpha$-TCP and $\beta$-TCP) formulations. Further details on this subject might be found in a topical review [230].

\section{Ion-substituted calcium orthophosphates}

Finally, one should very briefly mention on existence of carbonateapatite [367-369], chlorapatite [370-372], as well as on a great number of calcium orthophosphates with various ionic substitutions $[23,63,373,374]$. In principle, any ion in calcium orthophosphates might be substituted by other ion(s). Usually, the ion-substituted calcium orthophosphates are of a non-stoichiometric nature with just a partial ionic substitution and there are too many of them to be described here. Currently, this is a hot investigation topic; therefore, the readers are referred to the special literature $[23,63,373,374]$. In addition, there is a very good review, in which the structures of more than 75 chemically different apatites have been discussed [88].

To conclude this topic, it is interesting to note, that chemical elements not found in natural bones can be intentionally incorporated into calcium orthophosphate biomaterials to get special properties. For example, addition of $\mathrm{Ag}^{+}$[375-377], $\mathrm{Zn}^{2+}[377,378]$ and $\mathrm{Cu}^{2+}$ [377-379] has been used for imparting antimicrobial effect, while radioactive isotopes of ${ }^{90} \mathrm{Y}$ [380], ${ }^{153} \mathrm{Sm}$ [381-383] and ${ }^{186} \mathrm{Re}$ [381] have been incorporated into HA bioceramics and injected into knee joints to treat rheumatoid joint synovitis $[380,381,383]$. More to the point, apatites were found to incorporate individual molecules, such as water, oxygen and carbon dioxide [63].

\section{References}

1. Dorozhkin SV (2012) Calcium orthophosphates and human beings: a historical perspective from the 1770s until 1940. Biomatter 2: 53-70.

2. Dorozhkin SV (2013) A detailed history of calcium orthophosphates from 1770s till 1950. See comment in PubMed Commons below Mater Sci Eng C Mater Biol Appl 33: 3085-3110.

3. Lide DR (2005) The CRC handbook of chemistry and physics. 86th Ed, CRC Press, Boca Raton, Florida, 2544.

4. LeGeros RZ (1991) Calcium phosphates in oral biology and medicine. Monogr Oral Sci 15: 1-201.

5. Elliott JC (1994) Structure and chemistry of the apatites and other calcium orthophosphates. Studies in inorganic chemistry 18: 389

6. Amjad Z (1998) Calcium phosphates in biological and industrial systems.
Kluwer Academic Publishers: Boston, MA, USA.

7. Dorozhkin SV (2011) Calcium orthophosphates: occurrence, properties, biomineralization, pathological calcification and biomimetic applications. Biomatter 1: 121-164.

8. Dorozhkin SV (2012) Calcium orthophosphates: applications in nature, biology and medicine. 1 st Edtn,Pan Stanford: Singapore 854

9. Cantelar E, Lifante G, Calderon T, Melendrez R, Millan A etal.(2001) Optical characterisation of rare earths in natural fluorapatite. J Alloy Compd 323 324:851-854.

10. Ribeiro HB, Guedes KJ, Pinheiro MVB, Greulich-Weber S, Krambrock K (2005) About the blue and green colors in natural fluorapatite. Physica Status Solidi C 2:720-723

11. Lowenstam HA, Weiner S (1989) On biomineralization. Oxford University Press, 324.

12. McConnell D (1973) Apatite: its crystal chemistry, mineralogy, utilization, and geologic and biologic occurrences. Applied Mineralogy 5:111

13. Becker $P$ (1989) Phosphates and phosphoric acid: raw materials technology and economics of the wet process (Fertilizer science and technology series). $2^{\text {nd }}$ Ed, Marcel Dekker Inc : New York, USA, 760

14. Smith DK (1994) Calcium phosphate apatites in nature. In: Hydroxyapatite and related materials. Brown PW, Constantz B, Eds. CRC Press Inc.: Boca Raton, FL, USA

15. Cook PJ, Shergold JH, Davidson DF, (2005) Eds., Phosphate deposits of the world: phosphate rock resources. Cambridge University Press: Cambridge, MA, USA, 2:600

16. Mitchell L, Faust GT, Hendricks SB, Reynolds DS (1943) The mineralogy and genesis of hydroxylapatite. Am Miner, 28:356-371.

17. Zhang JZ, Guo L, Fischer CJ (2010) Abundance and chemical speciation of phosphorus in sediments of the Mackenzie river delta, the Chukchi sea and the Bering sea: importance of detrital apatite. Aquatic Geo chem 16: 353-371.

18. Omelon SJ1, Grynpas MD (2008) Relationships between polyphosphate chemistry, biochemistry and apatite biomineralization. Chem Rev 108: 4694 4715.

19. Jarvis I (1994) Phosphorite geochemistry: state-of-the-art and environmental concerns. Eclogae Geologicae Helvetiae 87: 643-700.

20. Glenn CR (1994) Phosphorus and phosphorites: sedimentology and environments of formation. Eclogae geol.helv 87:747-788

21. McClellan GH (1980) Mineralogy of carbonate fluorapatites (Francolites). J Geol Soc 137: 675-681.

22. Mcarthur JM (1985) Francolite geochemistry-compositional controls during formation, diagenesis, metamorphism and weathering. Geochim. Cosmochim. Acta 49: 23-35.

23. Pan Y, Fleet ME (2002) Compositions of the apatite-group minerals substitution mechanisms and controlling factors. In: Phosphates: geochemical geobiological and materials importance. Series: Reviews in Mineralogy and Geochemistry. Vol. 48. Hughes JM, Kohn M, Rakovan J, Eds. Mineralogical Society of America: Washington, D.C., USA, 13-49.

24. Zanin YN (2004) The classification of calcium phosphates of phosphorites Lithol Miner Resour 39: 281-282.

25. Henry TH (1850) On francolite, a supposed new mineral. Phil. Mag 36: 134 135.

26. Rogers AF(1922) Collophane, a much neglected mineral. Am J Sci 3: 269-276

27. Cao Q, Wen S, Li C, Bai S, Liu D (2013) Investigation on beneficiation strategy for collophane. Adv Mater Res 634-638: 3404-3411.

28. http://www.mindat.org/min-10072.html (accessed in February 2014).

29. Elorza J, Astibia H, Murelaga X, Pereda-Suberbiola X (1999) Francolite as a diagenetic mineral in dinosaur and other upper cretaceous reptile bones (Lano, Iberian peninsula): microstructural, petrological and geochemical features. Cretaceous Res 20:169-187.

30. Hubert B, Clvaro JJ, Chen JY (2005) Microbially mediated phosphatization in the Neoproterozoic Doushantuo Lagerstotte, South China. Bull Soc Gщol Fr, 176:355-361. 
Citation: Dorozhkin SV (2014) Calcium Orthophosphates: Occurrence, Properties and Major Applications. Bioceram Dev Appl 4: 081. doi: 10.4172/2090-5025.1000081

Page 13 of 20

31. Xiao S, Zhang Y, Knoll AH (1998) Three-dimensional preservation of algae and animal embryos in a neo proterozoic phosphorite. Nature 391:553-558.

32. Xiao S1, Yuan X, Knoll AH (2000) Eumetazoan fossils in terminal proterozoic phosphorites?Proc Natl Acad Sci U S A 97: 13684-13689.

33. Chakhmouradian AR (2006) Clinohydroxylapatite : a new apatite-group mineral from northwestern Ontario (Canada) and new data on the extent of $\mathrm{Na}-\mathrm{S}$ substitution in natural apatites. Eur J Mineral 18: 105-112.

34. Mason HE, Mccubbin FM, Smirnov AE, Phillips BL (2009) Solid-state NMR and IR spectroscopic investigation of the role of structural water and $F$ in carbonaterich fuorapatite. Am Miner 94:507-516.

35. http://www.mindat.org/gallery.php? $\min =9293$

36. Klein C(1901) Brushite from the island of Mona (between Haiti and Puerto Rico). Sitzber K Preuss Aka, 720-725.

37. Merrill GP (1917) On the calcium phosphate in meteoric stones. Am J Sci 43 : 322-324.

38. McCubbin FM, Nekvasil H (2008) Maskelynite-hosted apatite in the Chassigny meteorite: insights into late-stage magmatic volatile evolution in martian magmas. Am. Miner 93:676-684.

39. Tyrrell GW (1938) Apatite, nepheline, and rare-earth mining in the Kola Peninsula. Nature 141: 354-355.

40. Kogarko LN (1999) Problems of the genesis of giant apatite and rare metal deposits of the Kola Peninsula, Russia. Geology of Ore Deposits 41: 351-366.

41. Baturin GN (2012) Phosphorites of the Sea of Japan. Oceanology 52: 666-676

42. Ford AK A (1917) Remarkable crystal of apatite from Mt. Apatite, Auburn, Maine. Am J.Sci 44: 245-246.

43. Hogarth DD (1974) The discovery of apatite on the Lievre River, Quebec Mineral. Rec 5: 178-182.

44. van Velthuizen J(1992) Giant fluorapatite crystals: a question of locality Mineral Rec 23:459-463.

45. Trueman NA (1996) Substitutions for phosphate ions in apatite. Nature 210 937-938

46. Gilinskaya LG (2010) Organic radicals in natural apatites according to EPR data: potential genetic and paleoclimatic indicators. J Struct Chem 51: 471-481

47. Gilinskaya LG (2010) A stable perinaphthenyl radical in natural apatites. J Struct Chem 51: 761-764

48. Sanchez-Salcedo S, Vila M, Izquierdo-Barba I, Cicuéndez M, Vallet-Regi M (2010) Biopolymer-coated hydroxyapatite foams: a new antidote for heavy metal intoxication. J Mater Chem 20: 6956-6961.

49. White T, Ferraris C, Kim J, Madhavi S (2005) Apatite - an adaptive framework structure. In: Micro- and mesoporous mineral phases. Series: Reviews in Mineralogy and Geochemistry. Vol. 57. Ferraris G, Merlino S, Eds. Mineralogical Society of America: Washington, D.C., USA, 307-401.

50. Jacob KD, Reynolds DS (1928) Reduction of tricalcium phosphate by carbon Ind Eng Chem 20: 1204-1210.

51. Emsley J (2001) The shocking history of phosphorus: a biography of the devil's element. Pan Books, Macmillan, UK.

52. Van der Sluis S, Meszaros Y, Marchee WGJ, Wesselingh HA et al. (1987) The digestion of phosphate ore in phosphoric acid. Ind Eng Chem Res 26: 2501-2505.

53. Dorozhkin SV (1996) Fundamentals of the wet-process phosphoric acid production. 1. Kinetics and mechanism of the phosphate rock dissolution. Ind Eng. Chem. Res 35: 4328-4335.

54. Dorozhkin SV (1997) Fundamentals of the wet-process phosphoric acid production. 2. kinetics and mechanism of $\mathrm{CaSO} \cdot 0.5 \mathrm{H}_{2} \mathrm{O}$ surface crystallization and coating formation. Ind Eng Chem. Res 36: 467-473

55. Dorozhkin SV (1998) Ecological principles of wet-process phosphoric acid technology. J Chem Technol Biotechnol 71: 227-233.

56. Copson RL, Newton RH, Lindsay JD (1936) Superphosphate manufacture mixing phosphate rook with concentrated phosphoric acid. Ind. Eng. Chem 28 923-927.

57. Newton RH, Copson RL (1936) Superphosphate manufacture - composition of superphosphate made from phosphate rock and concentrated phosphoric acid. Ind. Eng. Chem 28: 1182-1186.

58. Rossete ALRM, Carneiro JMT, Bendassolli JA, Tavares CRO, Sant'Ana Filho CR (2008) Production of single superphosphate labeled with 34S. Scientia Agricola 65: 91-94.

59. Magda A, Pode V, Niculescu M, Muntean C, Bandur G etal. (2008) Studies on process of obtaining the fertilizers based on ammonium phosphates with addition of boric acid. Rev Chim Bucharest 59: 1340-1344.

60. Kijkowska R, Kowalski Z Pawlowska-Kozinska D, Wzorek Z Gorazda K (2007) Effect of purification from sulfates on phase composition of sodium tripolyphosphate obtained from wet-process phosphoric acid derived from Kola apatite. Phosphorus Sulfur 182: 2667-2683.

61. Abouzeid AZM (2007) Upgrading of phosphate ores - a review. Powder Handling and Processing 19: 92-109.

62. Abouzeid AZM (2008) Physical and thermal treatment of phosphate ores - an overview. Int. J. Mineral Process 85: 59-84.

63. Rey C, Combes C, Drouet C, Sfihi H (2006) Chemical diversity of apatites. Adv. Sci. Technol 49: 27-36.

64. O'Neill WC (2007) The fallacy of the calcium-phosphorus product. Kidney In 72: $792-796$

65. LeGeros RZ (2001) Formation and transformation of calcium phosphates: relevance to vascular calcification. Z Kardiol 90 Suppl 3: 116-124.

66. Becker A1, Epple M, Mḱller KM, Schmitz I (2004) A comparative study of clinically well-characterized human atherosclerotic plaques with histological chemical, and ultrastructural methods. J Inorg Biochem 98: 2032-2038.

67. Wopenka B, Pasteris JD( 2005) A mineralogical perspective on the apatite in bone. Mater Sci Eng C 25: 131-143.

68. Pasteris JD, Wopenka B, Valsami Jones E (2008) Bone and tooth mineralization: why apatite? Elements 4: 97-104

69. Sun Y, Hanley EN (2007) Jr. Calcium-containing crystals and osteoarthritis Curr Opin Orthoped 18:472-478.

70. Nakano T, Kaibara K, Tabata $Y$, Nagata N, Enomoto S, Marukawa E, Umakosh $Y(2002)$ Unique alignment and texture of biological apatite crystallites in typical calcified tissues analyzed by microbeam $\mathrm{x}$-ray diffractometer system. Bone 31 479-487.

71. Grynpas MD, Omelon S (2007) Transient precursor strategy or very small biological apatite crystals? Bone 41: 162-164.

72. Bazin D1, Dessombz A2, Nguyen C3, Ea HK3, Liotщ F3, et al. (2014) The status of strontium in biological apatites: an XANES/EXAFS investigation. $J$ Synchrotron Radiat 21: 136-142.

73. Lee JW, Sasaki K, Ferrara JD, Akiyama K, Sasaki T,etal.(2009) Evaluation of preferential alignment of biological apatite (BAp) crystallites in bone using transmission X-ray diffraction optics. J Jpn Ins Metal 73:786-793.

74. Ishimoto T, Sakamoto T, Nakano T (2010) Orientation of biological apatite in rat calvaria analyzed by microbeam X-ray diffractometer. Mater Sci Forum 638 642: $576-581$

75. Meneghini C1, Dalconi MC, Nuzzo S, Mobilio S, Wenk RH (2003) Rietveld refinement on $\mathrm{x}$-ray diffraction patterns of bioapatite in human fetal bones. Biophys J 84: 2021-2029.

76. Eagle RA1, Schauble EA, Tripati AK, Tḱtken T, Hulbert RC, et al. (2010) Body temperatures of modern and extinct vertebrates from (13)C-(18)O bond abundances in bioapatite. Proc Natl Acad Sci U S A 107: 10377-10382.

77. Cherkinsky A, Dantas MAT, Cozzuol MA (2013) Bioapatite 14C age of giant mammals from Brazil. Radiocarbon 55: 464-471.

78. Supovc M (2014) Isolation and preparation of nanoscale bioapatites from natural sources: a review. J Nanosci Nanotechnol 14: 546-563.

79. Brigger WC, Bdpckstrim H Mber den Dahllit, ein neues Mineral von жdegorden Bamle, Norwegen. Neues Jb. Miner. Geol. Paldoont. 1890, 223-224.

80. Skinner HCW (2005) Biominerals. Mineral Mag 69:621-641.

81. Daculsi G1, Bouler JM, LeGeros RZ (1997) Adaptive crystal formation in normal and pathological calcifications in synthetic calcium phosphate and related biomaterials. Int Rev Cytol 172: 129-191. 
Citation: Dorozhkin SV (2014) Calcium Orthophosphates: Occurrence, Properties and Major Applications. Bioceram Dev Appl 4: 081. doi: 10.4172/2090-5025.1000081

Page 14 of 20

82. Driessens FCM, Verbeeck RMH (1990) Biominerals. CRC Press: Boca Raton, FL, USA.

83. Clark NA (1931) The system $\mathrm{P} 2 \mathrm{O} 5-\mathrm{CaO}-\mathrm{H} 2 \mathrm{O}$ and the recrystallization of monocalcium phosphate. J Phys Chem 35: 1232-1238.

84. Brown PW (1992) Phase relationships in the ternary system CaO - P2O5 - H2O at 25AC. J Am Ceram Soc 75:17-22.

85. Martin RI, Brown PW (1997) Phase equilibria among acid calcium phosphates. J Am Ceram Soc 80: 1263-1266.

86. Kreidler ER, Hummel FA (1967) Phase relationships in the system SrO-P2O5 and the influence of water vapor on the formation of Sr4P2O9. Inorg Chem 6: 884-891.

87. Carayon MT, Lacout JL (2003) Study of the Ca/P atomic ratio of the amorphous phase in plasma-sprayed hydroxyapatite coatings. J Solid State Chem 172 339-350.

88. White TJ1, ZhiLi D (2003) Structural derivation and crystal chemistry of apatites Acta Crystallogr B 59: 1-16

89. Mathew M, Takagi S (2001) Structures of biological minerals in dental research J Res Natl Inst Stand Technol 106: 1035-1044

90. Wang L1, Nancollas GH (2008) Calcium orthophosphates: crystallization and dissolution. Chem Rev 108: 4628-4669.

91. Lynn AK1, Bonfield W (2005) A novel method for the simultaneous, titrant-free control of $\mathrm{pH}$ and calcium phosphate mass yield. Acc Chem Res 38: 202-207.

92. Leín B, Jansen JJ (2009) Thin calcium phosphate coatings for medical implants.Springer: New York, USA.

93. McDowell H, Gregory TM, Brown WE (1977) Solubility of Ca5(PO4)3OH in the system $\mathrm{Ca}(\mathrm{OH}) 2-\mathrm{H} 3 \mathrm{PO} 4-\mathrm{H} 2 \mathrm{O}$ at $5,15,25$, and 37 degree C. J Res Natl Bur Stand Sect A Phys Chem 81A:273-281.

94. Chow LC (2009) Next generation calcium phosphate-based biomaterials.Dent Mater J 28: 1-10.

95. Pan HB, Darvell BW (2009) Calcium phosphate solubility: the need for reevaluation. Cryst Growth Des 9: 639-645.

96. Fourcroy $\mathrm{AF}(1804) \mathrm{A}$ general system of chemical knowledge; and its application to the phenomena of nature and art. In eleven volumes. Translated from the original French by William Nicholson. Vol. III. Printed for Cadell and Davies, Strand; Longman and Rees, G. and J. Robinson, and J. Walker, Paternosterrow; Vernor and Hood, Poultry; Clarke and sons, Portugal-street; Cuthell and Martin, and Ogilvy and son, Holborn; and S. Bagster, Strand. London.

97. A dictionary of chemistry and mineralogy, with an account of the processes employed in many of the most important chemical manufactures. To which are added a description of chemical apparatus, and various useful tables of weights and measures, chemical instruments, \&c. \&c. Illustrated with fifteen engravings. By A. \& C. R. Aikin. Vol. II. London: Printed for John and Arthur Arch, Couninll; and William Phillips, George Yard, Lombard Street. 1807: 176.

98. Boonchom B (2009) Parallelogram-like microparticles of calcium dihydrogen phosphate monohydrate $(\mathrm{Ca}(\mathrm{H} 2 \mathrm{PO} 4) 2 \cdot \mathrm{H} 2 \mathrm{O})$ obtained by a rapid precipitation route in aqueous and acetone media. J Alloy Compd 482:199-202.

99. Kongteweelert S, Ruttanapun $C$, Thongkam M, Chaiyasith $P$, Woramongkonchai S, Boonchom AB (2013) Facile, alternative synthesis of spherical-like $\mathrm{Ca}(\mathrm{H} 2 \mathrm{PO} 4) 2 \cdot \mathrm{H} 2 \mathrm{O}$ nanoparticle by aqueous-methanol media. Adv Mater Res 717: 49-53

100. Tynsuaadu K (1990) Influence of silicic acid and glauconite on therma dehydration of $\mathrm{Ca}(\mathrm{H} 2 \mathrm{PO} 4) 2 \cdot \mathrm{H} 2 \mathrm{O}$. J Therm Anal 36: 1785-1793.

101. Xu J, Gilson DFR, Butler IS (1998) FT-Raman and high-pressure FT-infrared spectroscopic investigation of monocalcium phosphate monohydrate, $\mathrm{Ca}(\mathrm{H} 2 \mathrm{PO} 4) 2 \cdot \mathrm{H} 2 \mathrm{O}$. Spectrochim Acta A 54: 1869-1878.

102. Kister K, Heide H, Kinig R (1977) [Resorbable calcium phosphate ceramics under load (author's transl)]. Langenbecks Arch Chir 343: 173-181.

103. Huan Z, Chang J (2009) Novel bioactive composite bone cements based on the n-tricalcium phosphate $\square$ monocalcium phosphate monohydrate composite cement system. Acta Biomater 5: 1253-1264.

104. Dorozhkin SV (2013) Self-setting calcium orthophosphate formulations. J Funct Biomater 4: 209-311.

105. Budavari S, ONeil MJ, Smith A, Heckelman PE, Kinneary JF (1996) The
Merck Index: an encyclopedia of chemicals, drugs, and biologicals. 12th Ed Chapman \& Hall: USA.

106. Stein HH1, Kadzere CT, Kim SW, Miller PS (2008) Influence of dietary phosphorus concentration on the digestibility of phosphorus in monocalcium phosphate by growing pigs. J Anim Sci 86: 1861-1867.

107. Dorozhkin SV (2013) Calcium orthophosphates in dentistry. J Mater Sci Mater Med 24: 1335-1363.

108. Smalberger SA, Chien SH, Singh U, Henao J (2010) Relative agronomic effectiveness of phosphate rock compared with triple superphosphate for initial canola, wheat, or ryegrass, and residual wheat in two acid soils. Soil Sci 175:36-43.

109. Roscoe HE, Schorlemmer C (1879) A treatise on chemistry. Volume II: Metals. Part 1. Macmillan and Co., London, UK.

110. Moore GE (1865) On brushite, a new mineral occurring in phosphatic guano. Am J Sci 39: 43-44.

111. Ferreira A, Oliveira C, Rocha F (2003) The different phases in the precipitation of dicalcium phosphate dihydrate. J Cryst Growth 252: 599-611.

112. Oliveira C, Ferreira A, Rocha F (2007) Dicalcium phosphate dihydrate precipitation: characterization and crystal growth. Chem Eng Res Design 85 1655-1661.

113. Sivkumar GR, Girija EK, Kalkura SN, Subramanian C (1997) Crystallization and characterization of calcium phosphates: brushite and monetite. Crysta Res Technol 33: 197-205.

114. Madhurambal G, Subha R, Mojumdar SC (2009) Crystallization and therma characterization of calcium hydrogen phosphate dihydrate crystals. J Therm Anal Calorim 96: 73-76.

115. MacDowell H, Brown WE, Sutter JR (1971) Solubility study of calcium hydrogenphosphate: Ion pair formation. Inorg Chem 10: 1638-1643.

116. Landin M, Rowe RC, York P (1994) Structural changes during the dehydration of dicalcium phosphate dihydrate. Eur. J. Pharmac Sci 2: 245-252.

117. Curry NA, Jones DW (1971) Crystal structure of brushite, calcium hydrogen orthophosphate dihydrate: a neutron-diffraction investigation. J Chem Soc A Inorg Phys Theoret Chem 3725-3729.

118. Arsic J, Kaminski D, Poodt P, Vlieg E (2004) Liquid ordering at the brushite $\{010\}$ - water interface. Phys Rev B 69: 245406

119. Pan HB1, Darvell BW (2009) Solubility of dicalcium phosphate dihydrate by solid titration. Caries Res 43: 254-260.

120. Lundager-Madsen HE (2008) Optical properties of synthetic crystals of brushite (CaHPO4-2H2O). J Cryst Growth 310:617-623.

121. Qiu SR1, Orme CA (2008) Dynamics of biomineral formation at the nearmolecular level. Chem Rev 108: 4784-4822.

122. Mostashari SM, Haddadi H, Hashempoor Z (2006) Effect of deposited calcium hydrogen phosphate dihydrate on the flame retardancy imparted to cotton fabric. Asian J Chem 18: 2388-2390.

123. Shepard CU (1882) On two new minerals, monetite and monite, with a notice of pyroclasite. Am J Sci 23: 400-405.

124. Tas AC (2009) Monetite (CaHPO4) synthesis in ethanol at room temperature. J Am Ceram Soc 92: 2907-2912.

125. Chen GG, Luo GS, Yang LM, Xu JH, Sun Y, Wang JD (2005) Synthesis and size control of $\mathrm{CaHPO} 4$ particles in a two-liquid phase micro-mixing process. J Cryst Growth 279: 501-507.

126. Miyazaki T1, Sivaprakasam K, Tantry J, Suryanarayanan R (2009) Physical characterization of dibasic calcium phosphate dihydrate and anhydrate. J Pharm Sci 98: 905-916.

127. Eshtiagh-Hosseini $H$, Houssaindokht MR, Chahkandhi M, Youssefi A (2008) Preparation of anhydrous dicalcium phosphate, DCPA, through sol-ge process, identification and phase transformation evaluation. J Non-Cryst Solids 354: 3854-3857.

128. Tamimi F1, Torres J, Bassett D, Barralet J, Cabarcos EL (2010) Resorption of monetite granules in alveolar bone defects in human patients. Biomaterials 31: 2762-2769.

129. Takami K, Machimura H, Takado K, Inagaki M, Kawashima Y (1996) Nove 
Citation: Dorozhkin SV (2014) Calcium Orthophosphates: Occurrence, Properties and Major Applications. Bioceram Dev Appl 4: 081. doi: 10.4172/2090-5025.1000081

preparation of free flowing spherically granulated dibasic calcium phosphate anhydrous for direct tabletting. Chem Pharm Bull. 44: 868-870.

130. Percy J (1843) Notice of a new hydrated phosphate of lime. Mem Proc Chem Soc 2: 222-223.

131. Bjerrum N (1958) Calciumorthophosphate. I. Die Festen Calciumorthophosphate. II. Komplexbildung in Lisung von Calcium-und Phosphate-Ionen. Math. Fys. Medd. Dan. Vid. Selsk 31: 1-79.

132. LeGeros RZ (1985) Preparation of octacalcium phosphate (OCP): a direct fast method. Calcif Tissue Int 37: 194-197.

133. Nakahira A1, Aoki S, Sakamoto K, Yamaguchi S (2001) Synthesis and evaluation of various layered octacalcium phosphates by wet-chemical processing. J Mater Sci Mater Med 12: 793-800.

134. Arellano-JimeДnez MJ, GarciДa-GarciДa R, Reyes-Gasga J (2009) Synthesis and hydrolysis of octacalcium phosphate and its characterization by electron microscopy and X-ray diffraction. J Phys Chem Solids 70: 390-395.

135. Suzuki O (2010) Octacalcium phosphate: osteoconductivity and crysta chemistry. Acta Biomater 6: 3379-3387.

136. Miyatake N, Kishimoto KN, Anada T, Imaizumi H, Itoi E, Suzuki O (2009) Effect of partial hydrolysis of octacalcium phosphate on its osteoconductive characteristics. Biomaterials 30: 1005-1014.

137. Matsunaga K (2008) First-principles study of substitutional magnesium and zinc in hydroxyapatite and octacalcium phosphate. J Chem Phys 128: 245101.

138. Boanini E, Gazzano M, Rubini K, Bigi A (2010) Collapsed octacalcium phosphate stabilized by ionic substitutions. Cryst Growth Des 10: 3612-3617.

139. Brown WE (1962) Octacalcium phosphate and hydroxyapatite: crysta structure of octacalcium phosphate. Nature 196: 1048-1050.

140. Brown WE, Smith JP, Lehr JR, Frazier AW (1962) Octacalcium phosphate and hydroxyapatite: crystallographic and chemical relations between octacalcium phosphate and hydroxyapatite. Nature 196:1050-1055.

141. Pan HB1, Darvell BW (2009) Solid titration of octacalcium phosphate. Caries Res 43: 322-330.

142. Chow LC, Eanes ED (2001) Octacalcium phosphate. Monographs in Oral Science, Karger, Basel, Switzerland

143. Kakei M1, Sakae T, Yoshikawa M (2009) Electron microscopy of octacalcium phosphate in the dental calculus. J Electron Microsc (Tokyo) 58: 393-398.

144. Brown WE (1966) Crystal growth of bone mineral. Clin Orthop Relat Res 44 205-220.

145. Suzuki O (2010) Biological role of synthetic octacalcium phosphate in bone formation and mineralization. J Oral Biosci 52: 6-14.

146. lijima M1, Nelson DG, Pan Y, Kreinbrink AT, Adachi M, et al. (1996) Fluoride analysis of apatite crystals with a central planar OCP inclusion: concerning the role of F-ions on apatite/OCP/apatite structure formation. Calcif Tissue Int 59: 377-384.

147. Bodier-Houllщ P, Steuer P, Voegel JC, Cuisinier FJG (1998) Firs experimental evidence for human dentine crystal formation involving conversion of octacalcium phosphate to hydroxyapatite. Acta Crystallogr D Biol Crystallogr 54: 1377-1381.

148. Rodrэguez-Herncndez AG, Ferncndez ME, Carbajal-de-la-Torre G, GarcэaGarcэa R, Reyes-Gasga (2005) J Electron microscopy analysis of the central dark line defect of the human tooth enamel. Mater Res Soc Symp Proc 839: 157-162.

149. Tomazic BB, Brown WE, Shoen FJ (1994) Physicochemical properties of calcific deposits isolated from porcine bioprosthetic heart valves removed from patients following $2-13$ years function. J Biomed Mater Res 28: 35-47.

150. Nancollas GH, Wu W (2000) Biomineralization mechanisms: a kinetics and interfacial energy approach. J Cryst Growth 211: 137-142.

151. Suzuki O, Kamakura S, Katagiri T, Nakamura M, Zhao B (2006) Bone formation enhanced by implanted octacalcium phosphate involving conversion into Ca-deficient hydroxyapatite. Biomaterials 27: 2671-2681.

152. Kikawa T1, Kashimoto O, Imaizumi H, Kokubun S, Suzuki O (2009) Intramembranous bone tissue response to biodegradable octacalcium phosphate implant. Acta Biomater 5: 1756-1766.
153. Murakami $Y 1$, Honda $Y$, Anada T, Shimauchi H, Suzuki O (2010) Comparative study on bone regeneration by synthetic octacalcium phosphate with various granule sizes. Acta Biomater 6: 1542-1548.

154. Suzuki O (2013) Octacalcium phosphate (OCP)-based bone substitute materials. Jpn Dent Sci Rev 49: 58-71.

155. Bredig MA, Franck HH, Fḱlnder H (1932) Beitrogge zur Kenntnis der KalkPhosphorsqure-Verbindungen. II. Z Elktrochem Angew. P 38: 158-164.

156. Trimel G (1932) Beitroge zur Kenntnis des Systems KalziumoxydPhosphorpentoxyd. Mitt Kaiser-Wilhelm-Inst Eisenforsch dḱsseldorf 14: 25 34.

157. Tao J, Jiang W, Zhai H, Pan H, Xu X, etal.(2008) Structural components and anisotropic dissolution behaviors in one hexagonal single crystal of n-tricalcium phosphate. Cryst Growth Des 8: 2227-2234.

158. Tao J, Pan H, Zhai H, Wang J, Li L, etal. (2009) Controls of tricalcium phosphate single-crystal formation from its amorphous precursor by interfacial energy. Cryst Growth Des 9:3154-3160.

159. Hou XJ, Mao KY, Chen DF (2008) Bone formation performance of betatricalcium phosphate sintered bone. J Clin Rehabil Tiss Eng Res 12: 9627 9630.

160. Santos CFL, Silva AP, Lopes L, Pires I, Correia IJ (2012) Design and production of sintered n-tricalcium phosphate 3D scaffolds for bone tissue regeneration. Mater Sci Eng C 32: 1293-1298.

161. Lee NH, Hwang KH, Lee JK (2013) Fabrication of biphasic calcium phosphate bioceramics from the recycling of bone ash. Adv Mater Res 610-613: 23282331.

162. Ito A, LeGeros RZ (2008) Magnesium- and zinc-substituted beta-tricalcium phosphates as potential bone substitute biomaterials. Key Eng Mater 377 : 85-98

163. Kannan S, Goetz-Neunhoeffer F, Neubauer J, Ferreira JMF (2009) Synthesis and structure refinement of zinc-doped n-tricalcium phosphate powders. J Am Ceram Soc 92: 1592-1595.

164. Kannan S1, Goetz-Neunhoeffer F, Neubauer J, Pina S, Torres PM, et al. (2010) Synthesis and structural characterization of strontium- and magnesium-co-substituted beta-tricalcium phosphate. Acta Biomater 6: 571 576 .

165. Araњjo JC, Sader MS, Moreira EL, Moraes VCA, LeGeros RZ, etal.(2009) Maximum substitution of magnesium for calcium sites in Mg-n-TCP structure determined by X-ray powder diffraction with the Rietveld refinement. Mater Chem Phys 118:337-340.

166. Karlinsey RL, Mackey AC (2009) Solid-state preparation and dental application of an organically modified calcium phosphate. J Mater Sci 44 346-349.

167. Karlinsey RL1, Mackey AC, Walker ER, Frederick KE (2010) Preparation, characterization and in vitro efficacy of an acid-modified beta-TCP material for dental hard-tissue remineralization.Acta Biomater 6: 969-978.

168. Karlinsey RL1, Mackey AC, Walker ER, Frederick KE (2010) Surfactantmodified beta-TCP: structure, properties, and in vitro remineralization of subsurface enamel lesions. J Mater Sci Mater Med 21: 2009-2020.

169. Yashima M, Sakai A, Kamiyama T, Hoshikawa A (2003) Crystal structure analysis of $n$-tricalcium phosphate $\mathrm{Ca} 3(\mathrm{PO} 4) 2$ by neutron powder diffraction. J Solid State Chem 175: 272-277.

170. Yin X, Stott MJ, Rubio A (2003) a- and n-tricalcium phosphate: a density functional study. Phys. Rev. B 68:205

171. Liang L, Rulis $P$, Ching WY (2010) Mechanical properties, electronic structure and bonding of a- and n-tricalcium phosphates with surface characterization Acta Biomater 6:3763-3771.

172. Kumar AR, Kalainathan S (2010) Microhardness studies on calcium hydrogen phosphate (brushite) crystals. Mater Res Bull 45:1664-1667.

173. Pan HB1, Darvell BW (2009) Solubility of TTCP and beta-TCP by solid titration. Arch Oral Biol 54: 671-677.

174. Wang W, Itoh S, Yamamoto N, Okawa A, Nagai A (2010) Electrical polarization of n-tricalcium phosphate ceramics. J Am Ceram Soc 93: 2175-2177.

175. Frondel C (1941) Whitlockite: a new calcium phosphate, Ca3(PO4)2. Am 
Citation: Dorozhkin SV (2014) Calcium Orthophosphates: Occurrence, Properties and Major Applications. Bioceram Dev Appl 4: 081. doi: 10.4172/2090-5025.1000081

Page 16 of 20

Mineral 26: $145-152$

176. Li X1, Ito A, Sogo Y, Wang X, LeGeros RZ (2009) Solubility of Mg-containing beta-tricalcium phosphate at 25 degrees C. Acta Biomater 5: 508-517.

177. Kodaka T, Debari K, Higashi S (1988) Magnesium-containing crystals in human dental calculus. J Electron Microsc (Tokyo) 37: 73-80

178. Reid JD1, Andersen ME (1993) Medial calcification (whitlockite) in the aorta. Atherosclerosis 101: 213-224

179. Scotchford CA1, Ali SY (1995) Magnesium whitlockite deposition in articular cartilage: a study of 80 specimens from 70 patients. Ann Rheum Dis 54: 339344.

180. P'ng CH, Boadle R, Horton M, Bilous M, Bonar F (2008) Magnesium whitlockite of the aorta. Pathology 40: 539-540.

181. Horch HH1, Sader R, Pautke C, Neff A, Deppe H, et al. (2006) Synthetic pure-phase beta-tricalcium phosphate ceramic granules (Cerasorb) for bone regeneration in the reconstructive surgery of the jaws. Int $\mathrm{J}$ Oral Maxillofac Surg 35: 708-713.

182. Ogose $\mathrm{A} 1$, Kondo $\mathrm{N}$, Umezu H, Hotta T, Kawashima H, et al. (2006) Histological assessment in grafts of highly purified beta-tricalcium phosphate (OSferion) in human bones. Biomaterials 27: 1542-1549.

183. Kamitakahara M1, Ohtsuki C, Miyazaki T (2008) Review paper: behavior of ceramic biomaterials derived from tricalcium phosphate in physiological condition. J Biomater Appl 23: 197-212.

184. Liu Y, Pei GX, Shan J, Ren GH (2008) New porous beta-tricalcium phosphate as a scaffold for bone tissue engineering. J Clin Rehabil Tiss Eng Res 12: 4563-4567.

185. Epstein NE (2009) Beta tricalcium phosphate: observation of use in 100 posterolateral lumbar instrumented fusions. Spine J 9: 630-638.

186. GУMngУЖrmУMX $\square$ C1, КФБІФБУї A, Akay MT, Kolankaya D (2010) The effects of maternal exposure to food additive E341 (tricalcium phosphate) on foetal development of rats. Environ Toxicol Pharmacol 29: 111-116.

187. Welch JH, Gutt W (1961) High-temperature studies of the system calcium oxide-phosphorus pentoxide. J Chem Soc 4442-4444.

188. Jokic B, Jankovic-Castvan I, Veljovic DJ, Bucevac D, Obradovic-Djuricic K, etal.(2007) Synthesis and settings behavior of a-TCP from calcium deficient hydroxyapatite obtained by hydrothermal method. J Optoelectron. Adv Mater 9: 1904-1910.

189. Nurse RW, Welch JB, Gun W (1959) High-temperature phase equilibria in the system dicalcium silicate - tricalcium phosphate. J Chem Soc 1077-1083.

190. Sayer M1, Stratilatov AD, Reid J, Calderin L, Stott MJ, et al. (2003) Structure and composition of silicon-stabilized tricalcium phosphate. Biomaterials 24 : 369-382.

191. Reid JW1, Pietak A, Sayer M, Dunfield D, Smith TJ (2005) Phase formation and evolution in the silicon substituted tricalcium phosphate/apatite system. Biomaterials 26: 2887-2897.

192. Reid JW1, Tuck L, Sayer M, Fargo K, Hendry JA (2006) Synthesis and characterization of single-phase silicon-substituted alpha-tricalcium phosphate. Biomaterials 27: 2916-2925.

193. Kanazawa T, Umegaki T, Uchiyama N(1982) Thermal crystallisation of amorphous calcium phosphate to a-tricalcium phosphate. J Chem Tech Biotechnol 32:399-406.

194. TenHuisen KS1, Brown PW (1998) Formation of calcium-deficient hydroxyapatite from alpha-tricalcium phosphate. Biomaterials 19: 2209-2217.

195. Durucan C1, Brown PW (2000) alpha-Tricalcium phosphate hydrolysis to hydroxyapatite at and near physiological temperature. J Mater Sci Mater Med 11: 365-371.

196. Durucan C, Brown PW (2002) Kinetic model for a-tricalcium phosphate hydrolysis. J Am Ceram Soc 85: 2013-2018.

197. Camirщ CL1, Gbureck U, Hirsiger W, Bohner M (2005) Correlating crystallinity and reactivity in an alpha-tricalcium phosphate. Biomaterials 26: 2787-2794.

198. Yin X1, Stott MJ (2005) Theoretical insights into bone grafting siliconstabilized alpha-tricalcium phosphate. J Chem Phys 122: 024709

199. Yin X1, Stott MJ (2006) Surface and adsorption properties of alpha-tricalcium phosphate. J Chem Phys 124: 124701.

200. Jones HB (1845) Contributions to the chemistry of the urine. On the variations in the alkaline and earthy phosphates in the healthy state, and on the alkalescence of the urine from fixed alkalies. Phil Trans R Soc Lond 135:335349

201. Dorozhkin SV (2012) Amorphous calcium orthophosphates: nature, chemistry and biomedical applications. Int J Mater Chem 2:19-46.

202. Blumenthal NC, Posner AS, Holmes JM (1972) Effect of preparation conditions on the properties and transformation of amorphous calcium phosphate. Mater Res Bull 7: 1181-1190.

203. Termine JD, Peckauskas RA, Posner AS (1970) Calcium phosphate formation in vitro. II. Effects of environment on amorphous-crystalline transformation. Arch Biochem Biophys 140: 318-325.

204. Posner AS, Betts F (1975) Synthetic amorphous calcium phosphate and its relation to bone mineral structure. Acc Chem Res 8: 273-281.

205. Elliott JC (1998) Recent studies of apatites and other calcium orthophosphates In: Les matщriaux en phosphate de calcium. Brws E, Hardouin P, Sauramps Medical: Montpellier, France, 25-66.

206. Li Y1, Weng W (2007) In vitro synthesis and characterization of amorphous calcium phosphates with various $\mathrm{Ca} / \mathrm{P}$ atomic ratios. J Mater Sci Mater Med 18: $2303-2308$

207. Tadic D1, Peters F, Epple M (2002) Continuous synthesis of amorphous carbonated apatites. Biomaterials 23: 2553-2559.

208. Keller L1, Dollase WA (2000) X-ray determination of crystalline hydroxyapatite to amorphous calcium-phosphate ratio in plasma sprayed coatings. J Biomed Mater Res 49: 244-249.

209. Kumar R, Cheang $P$, Khor KA (2004) Phase composition and heat of crystallization of amorphous calcium phosphate in ultra-fine radio frequency suspension plasma sprayed hydroxyapatite powders. Acta Mater 52:1171 1181.

210. Harries JE, Hukins DWL, Hasnain SS (1986) Analysis of the EXAFS spectrum of hydroxyapatite. J Phys C: Solid State Phys 19: 6859-6872.

211. Harries JE, Hukins DWL, Holt C, Hasnain SS (1987) Conversion of amorphous calcium phosphate into hydroxyapatite investigated by EXAFS spectroscopy. J Cryst Growth 84: 563-570.

212. Taylor MG1, Simkiss K, Simmons J, Wu LN, Wuthier RE (1998) Structural studies of a phosphatidyl serine-amorphous calcium phosphate complex. Cell Mol Life Sci 54: 196-202.

213. Peters F, Schwarz K, Epple M (2000) The structure of bone studied with synchrotron X-ray diffraction, X-ray absorption spectroscopy and thermal analysis. Thermochim. Acta 361:131-138.

214. Posner AS, Betts F, Blumenthal NC (1980) Formation and structure of synthetic and bone hydroxyapatite. Progr Cryst Growth Char 3: 49-64.

215. Boskey AL (1997) Amorphous calcium phosphate: the contention of bone. $J$ Dent Res 76: 1433-1436.

216. Onuma K, Ito A (1998) Cluster growth model for hydroxyapatite. Chem. Mater 10: $3346-3351$

217. Tadic D, Epple M (2002) Amorphous calcium phosphates as bone substitution materials. Eur J Trauma 28: 136-137.

218. Combes C1, Rey C (2010) Amorphous calcium phosphates: synthesis, properties and uses in biomaterials. Acta Biomater 6: 3362-3378.

219. Bache $F(1819)$ A system of chemistry for the use of students of medicine William Fry, Philadelphia 624

220. Wilson RM1, Elliott JC, Dowker SE, Rodriguez-Lorenzo LM (2005) Rietveld refinements and spectroscopic studies of the structure of Ca-deficient apatite. See comment in PubMed Commons below Biomaterials 26: 1317-1327.

221. Zahn D, Hochrein $O$ (2008) On the composition and atomic arrangement of calcium-deficient hydroxyapatite: an ab-initio analysis. J Solid State Chem 181: $1712-1716$.

222. Ivanova T I, Frank-Kamenetskaya OV, Kol'tsov AB, Ugolkov VL (2001) Crystal structure of calcium-deficient carbonated hydroxyapatite therma decomposition. J Solid State Chem 160: 340-349. 
Citation: Dorozhkin SV (2014) Calcium Orthophosphates: Occurrence, Properties and Major Applications. Bioceram Dev Appl 4: 081. doi: 10.4172/2090-5025.1000081

Page 17 of 20

223. Sinha A, Nayar S, Agrawal A, Bhattacharyya D, Ramachandrarao P (2003) Synthesis of nanosized and microporous precipitated hydroxyapatite in synthetic polymers and biopolymers. J Am Ceram Soc 86: 357-359.

224. Mayer I, Jacobsohn O, Niazov T, Werckmann J, lliescu M, etal. (2003) Manganese in precipitated hydroxyapatites. Eur. J Inorg Chem 1445-1451.

225. Vallet-RegiД М, RodriДguez-Lorenzo LM, Salinas AJ (1997) Synthesis and characterisation of calcium deficient apatite. Solid State lonics 101-103: 1279-1285.

226. Siddharthan A1, Seshadri SK, Sampath Kumar TS (2004) Microwave accelerated synthesis of nanosized calcium deficient hydroxyapatite. J Mater Sci Mater Med 15: 1279-1284

227. Hutchens SA1, Benson RS, Evans BR, O'Neill HM, Rawn CJ (2006) Biomimetic synthesis of calcium-deficient hydroxyapatite in a natural hydrogel. Biomaterials 27: 4661-4670.

228. Mochales C, Wilson RM, Dowker SEP, Ginebra MP (2011) Dry mechanosynthesis of nanocrystalline calcium deficient hydroxyapatite: structural characterization. J Alloy Compd 509: 7389-7394.

229. Bre's EF, Duhoo T, Leroy N, Lemaitre (2005) J. Evidence of a transient phase during the hydrolysis of calcium-deficient hydroxyapatite. Zeitschrift fuer Metallkunde 96: 503-506

230. Dorozhkin SV (2012) Biphasic, triphasic and multiphasic calcium orthophosphates. Acta Biomater 8: 963-977.

231. Dorozhkina El, Dorozhkin SV (2002) Mechanism of the solid-state transformation of a calcium-deficient hydroxyapatite (CDHA) into biphasic calcium phosphate (BCP) at elevated temperatures. Chem Mater 14: 42674272.

232. Dorozhkin SV (2003) Mechanism of solid-state conversion of nonstoichiometric hydroxyapatite to diphase calcium phosphate. Russ Chem Bull 52: $2369-2375$

233. Rodrэguez-Lorenzo LM (2005) Studies on calcium deficient apatites structure by means of MAS-NMR spectroscopy. J Mater Sci Mater Med 16: 393-398.

234. Brown PW, Martin RI (1999) An analysis of hydroxyapatite surface layer formation. J Phys Chem B 103:1671-1675.

235. Honghui Z, Hui L, Linghong G (2007) Molecular and crystal structure characterization of calcium-deficient apatite. Key Eng Mater 330-332: 119122.

236. Viswanath B, Shastry VV, Ramamurty U, Ravishankar N(2010) Effect of calcium deficiency on the mechanical properties of hydroxyapatite crystals. Acta Mater 58: 4841-4848.

237. Matsunaga K (2008) Theoretical investigation of the defect formation mechanism relevant to nonstoichiometry in hydroxyapatite. Phys. Rev. B 77: 104106

238. Bourgeois B1, Laboux O, Obadia L, Gauthier O, Betti E, et al. (2003) Calciumdeficient apatite: a first in vivo study concerning bone ingrowth. J Biomed Mater Res A 65: 402-408.

239. Liu TY, Chen SY, Liu DM, Liou SC (2005) On the study of BSA-loaded calcium-deficient hydroxyapatite nano-carriers for controlled drug delivery. $J$ Control Release 107: 112-121.

240. Tsuchida T, Yoshioka T, Sakuma S, Takeguchi T, Ueda W (2008) Synthesis of biogasoline from ethanol over hydroxyapatite catalyst. Ind Eng Chem Res 47: $1443-1452$

241. Elliott JC, Mackie PE, Young RA (1973) Monoclinic hydroxyapatite.Science 180: 1055-1057.

242. Rangavittal N1, Landa-Ccnovas AR, Gonzclez-Calbet JM, Vallet-Regэ M (2000) Structural study and stability of hydroxyapatite and beta-tricalcium phosphate: two important bioceramics. J Biomed Mater Res 51: 660-668.

243. Kim JY, Fenton RR, Hunter BA, Kennedy BJ (2000) Powder diffraction studies of synthetic calcium and lead apatites. Austr J Chem 53: 679-686.

244. KAY MI, YOUNG RA, POSNER AS (1964) CRYSTAL STRUCTURE OF HYDROXYAPATITE. Nature 204: 1050-1052.

245. Calderin L, Stott MJ, Rubio A (2003) Electronic and crystallographic structure of apatites. Phys Rev B 67:134106.

246. Rulis P, Ouyang L, Ching WY (2004) Electronic structure and bonding in calcium apatite crystals: hydroxyapatite, fluorapatite, chlorapatite and bromapatite. Phys. Rev. B 70: 155104

247. Snyders R, Music D, Sigumonrong D, Schelnberger B, Jensen J, etal. (2007) Experimental and ab initio study of the mechanical properties of hydroxyapatite. Appl Phys Lett 90: 193902.

248. Ching WY1, Rulis P, Misra A (2009) Ab initio elastic properties and tensile strength of crystalline hydroxyapatite. Acta Biomater 5: 3067-3075.

249. Treboux G, Layrolle P, Kanzaki N, Onuma K, Ito A (2000) Symmetry of Posner's cluster. J Am. Chem Soc 122: 8323-8324.

250. Yin X, Stott MJ (2003) Biological calcium phosphates and Posner's cluster. J Chem Phys 118: 3717-3723.

251. Kanzaki N1, Treboux G, Onuma K, Tsutsumi S, Ito A (2001) Calcium phosphate clusters. Biomaterials 22: 2921-2929.

252. Calderin L, Dunfield D, Stott MJ (2005) Shell-model study of the lattice dynamics of hydroxyapatite. Phys Rev B 2005 72: 224-304

253. Tanaka Y, Iwasaki T, Nakamura M, Nagai A, Katayama K,etal. (2010) Polarization and microstructural effects of ceramic hydroxyapatite electrets J Appl Phys 107: 014107

254. Tanaka Y, Iwasaki T, Katayama K, Hojo J, Yamashita K (2010) Effect of ionic polarization on crystal structure of hydroxyapatite ceramic with hydroxide nonstoichiometry. J Jpn Soc Powder and Powder Metall 57: 520-528.

255. Tofail SAM, Baldisserri C, Haverty D, McMonagle JB, Erhart (2009) J Pyroelectric surface charge in hydroxyapatite ceramics. J Appl Phys 106: 106104

256. Kawabata K, Yamamoto T (2010) First-principles calculations of the elastic properties of hydroxyapatite doped with divalent ions. J Ceram Soc Jpn 118 548-549.

257. Matsunaga K, Kuwabara A (2007) First-principles study of vacancy formation in hydroxyapatite. Phys Rev B 75:014102

258. De Leeuw NH (2010) Computer simulations of structures and properties of the biomaterial hydroxyapatite. J Mater Chem 20: 5376-5389.

259. Corno M1, Rimola A, Bolis V, Ugliengo P (2010) Hydroxyapatite as a key biomaterial: quantum-mechanical simulation of its surfaces in interaction with biomolecules. Phys Chem Chem Phys 12: 6309-6329.

260. El Briak-Benabdeslam H1, Ginebra MP, Vert M, Boudeville P (2008) Wet or dry mechanochemical synthesis of calcium phosphates? Influence of the water content on DCPD-CaO reaction kinetics.Acta Biomater 4: 378-386.

261. Markovic M, Fowler BO, Tung MS (2004) Preparation and comprehensive characterization of a calcium hydroxyapatite reference material. J Res Nat Inst Stand Technol 109: 553-568.

262. Bonel G1, Heughebaert JC, Heughebaert M, Lacout JL, Lebugle A (1988) Apatitic calcium orthophosphates and related compounds for biomaterials preparation.Ann N Y Acad Sci 523: 115-130

263. Narasaraju TSB, Phebe DE (1996) Some physico-chemical aspects of hydroxylapatite. J Mater Sci 31: 1-21.

264. Riman RE, Suchanek WL, Byrappa K, Chen CW, Shuk P, etal.(2002) Solution synthesis of hydroxyapatite designer particulates. Solid State Ionics 151: 393-402.

265. Koutsopoulos S (2002) Synthesis and characterization of hydroxyapatite crystals: a review study on the analytical methods. J Biomed Mater Res 62 : 600-612.

266. Norton J, Malik KR, Darr JA, Rehman IU (2006) Recent developments in processing and surface modification of hydroxyapatite. Adv Appl Ceram 105: 113-139.

267. Sadat-Shojai M1, Khorasani MT, Dinpanah-Khoshdargi E, Jamshidi A (2013) Synthesis methods for nanosized hydroxyapatite with diverse structures. Acta Biomater 9: 7591-7621.

268. Rakovan J (2002) Growth and surface properties of apatite. In: Phosphates: geochemical, geobiological and materials importance. Reviews in Mineralogy and Geochemistry, Hughes JM, Kohn M, Rakovan J, Eds. Mineralogical Society of America: Washington, D.C., USA, 48: 51-86.

269. Dorozhkin SV (2012) Dissolution mechanism of calcium apatites in acids: A review of literature.World J Methodol 2: 1-17. 
Citation: Dorozhkin SV (2014) Calcium Orthophosphates: Occurrence, Properties and Major Applications. Bioceram Dev Appl 4: 081. doi: 10.4172/2090-5025.1000081

Page 18 of 20

270. Suchanek W, Yoshimura M (1998) Processing and properties of hydroxyapatite-based biomaterials for use as hard tissue replacement implants. J Mater Res 13: 94-117.

271. Sun L1, Berndt CC, Gross KA, Kucuk A (2001) Material fundamentals and clinical performance of plasma-sprayed hydroxyapatite coatings: a review. J Biomed Mater Res 58: 570-592.

272. Ong JL1, Chan DC (2000) Hydroxyapatite and their use as coatings in dental implants: a review.Crit Rev Biomed Eng 28: 667-707.

273. Dey A, Mukhopadhyay AK, Gangadharan S, Sinha MK, Basu D(2009) Characterization of microplasma sprayed hydroxyapatite coating. J Therm Spray Technol 18: 578-592.

274. Dorozhkin SV (2012) Calcium orthophosphate coatings, films and layers. Prog Biomater 1: 1-40.

275. Yuan Y, Huang P, Peng Q, Zhang C, Weng J (2009) Osteogenesis of porous bioceramics scaffolds consisted of hydroxyapatite spherules after implanted in different non-osseous sites. Mater Sci Forum 610-613: 1335-1338.

276. Engin NO, Tas AC (1999) Manufacture of macroporous calcium hydroxyapatite bioceramics. J Eur Ceram Soc 19: 2569-2572.

277. Mangano C1, Piattelli A, Perrotti V, lezzi G (2008) Dense hydroxyapatite inserted into postextraction sockets: a histologic and histomorphometric 20year case report. J Periodontol 79: 929-933.

278. Bernardi G (1965) Chromatography of nucleic acids on hydroxyapatite. Nature 206: 779-783.

279. Doonan S (2004) Chromatography on hydroxyapatite. Methods Mol Biol 244 191-194.

280. Brand M, Rampalli S, Chaturvedi CP, Dilworth FJ (2008) Analysis of epigenetic modifications of chromatin at specific gene loci by native chromatin immunoprecipitation of nucleosomes isolated using hydroxyapatite chromatography. Nat. Protoc 3: 398-409.

281. Hou Y1, Morrison CJ, Cramer SM (2011) Classification of protein binding in hydroxyapatite chromatography: synergistic interactions on the molecular scale. Anal Chem 83: 3709-3716.

282. Hilbrig F1, Freitag R (2012) Isolation and purification of recombinant proteins, antibodies and plasmid DNA with hydroxyapatite chromatography. Biotechnol J 7: 90-102.

283. Uskokovi $\square$ V1, Uskokovi $\square$ DP (2011) Nanosized hydroxyapatite and other calcium phosphates: chemistry of formation and application as drug and gene delivery agents. J Biomed Mater Res B Appl Biomater 96: 152-191.

284. Chen F1, Huang P, Zhu YJ, Wu J, Zhang CL, et al. (2011) The photoluminescence, drug delivery and imaging properties of multifunctional Eu3+/Gd3+ dual-doped hydroxyapatite nanorods.Biomaterials 32: 9031 9039.

285. Li D1, Liang Z, Chen J, Yu J, Xu R (2013) AlE luminogen bridged hollow hydroxyapatite nanocapsules for drug delivery. Dalton Trans 42: 9877-9883.

286. Long T, Guo YP, Liu YZ, Zhu ZA (2013) Hierarchically nanostructured mesoporous carbonated hydroxyapatite microspheres for drug delivery systems with high drug-loading capacity. RSC Adv 3: 24169-24176.

287. Feng D, Shi J, Wang X, Zhang L, Cao S (2013) Hollow hybrid hydroxyapatite microparticles with sustained and $\mathrm{pH}$-responsive drug delivery properties. RSC Adv 3: 24975-24982.

288. Niwa M1, Sato T, Li W, Aoki H, Aoki H, et al. (2001) Polishing and whitening properties of toothpaste containing hydroxyapatite. J Mater Sci Mater Med 12: $277-281$.

289. Kim BI, Jeong SH, Jang SO, Kim KN, Kwon HK, (2006)Tooth whitening effect of toothpastes containing nano-hydroxyapatite. Key Eng Mater 309-311: 541544.

290. Pietrasik J, Szustakiewicz K, Zaborski M, Haberko K (2008) Hydroxyapatite: an environmentally friendly filler for elastomers. Mol Cryst Liq Cryst 483:172178.

291. Bailliez S, Nzihou A, Bwche E, Flamant G (2004) Removal of lead (Pb) by hydroxyapatite sorbent. Process Saf Environ 82: 175-180.

292. Corami A1, Mignardi S, Ferrini V (2008) Cadmium removal from single- and multi-metal $(\mathrm{Cd}+\mathrm{Pb}+\mathrm{Zn}+\mathrm{Cu})$ solutions by sorption on hydroxyapatite. J
Colloid Interface Sci 317: 402-408.

293. Phonthammachai N, Ziyi Z, Jun G, Fan HY, White TJ (2008) Synthesis of high performance hydroxyapatite-gold catalysts for $\mathrm{CO}$ oxidation. Gold Bull 41: $42-50$

294. Chen W, Huang ZL, Liu Y, He QJ (2008) Preparation and characterization of a novel solid base catalyst hydroxyapatite loaded with strontium. Catalysis Comm 9: 516-521.

295. Domэnguez MI, Romero-Sarria F, Centeno MA, Odriozola JA (2009) Gold/ hydroxyapatite catalysts. Synthesis, characterization and catalytic activity to CO oxidation. Appl Catalysis B 87: 245-251.

296. Xu J1, White T, Li P, He C, Han YF (2010) Hydroxyapatite foam as a catalys for formaldehyde combustion at room temperature. J Am Chem Soc 132 $13172-13173$.

297. Encyclopaedia; or, a dictionary of arts, sciences, and miscellaneous literature; Con?tructed on a Plan, by which the different sciences and arts are dige?ted into the Form of di?tinct treatises or systems, comprihending the history, theory, and practice, of each, According to the Late?t Di?coveries and Improvements; and full explanations given of the various detached parts of knowledge, where relating to Natural and Artificial Objects, or to Matters Ecclesiastical, Civil, Military, Commercial, \&c. Including Elucidations of the mo?t important Topics relative to Religion, Morals, Manners, and the Oeconomy of Life. Together with A Description of all the Countries, Cities, principle Mountains, Seas, Rivers, \&c. throughout the World; A General History, Ancient and Modern, of the different Empires, Kingdoms, and States; and An Account of the Lives of the mo?t Eminent Per?ons in every Nation, from the earliest ages down to the pre?ent times. The first American edition, in eighteen volumes, greatly improved. Vol. XIV. PAS - PLA Philadelphia: printed by Thomas Dobson, at the Stone-house, No 41, South second-street. 1798, $797 \mathrm{pp}$.

298. Busch S, Dolhaine H, Duchesne A, Heinz S, Hochrein O, etal. (1999) Biomimetic morphogenesis of fluorapatite-gelatin composites: fractal growth the question of intrinsic electric fields, core / shell assemblies, hollow spheres and reorganization of denatured collagen. Eur J Inorg Chem 1643-1653.

299. Wu YJ, Tseng YH, Chan JCC (2010) Morphology control of fluorapatite crystallites by citrate ions. Cryst Growth Des 10: 4240-4242.

300. Mazelsky R, Hopkins RH, Kramer WE (1968) Czochralski-growth of calcium fluorophosphates. J Cryst Growth 3-4: 260-264.

301. Loutts GB, Chai BHT (1993) Growth of high-quality single crystals of FAP (Ca5(PO4)3F) and its isomorphs. Proc SPIE - Int Soc Optical Eng 1863 31-34.

302. Warren RW (1972) Defect centers in calcium fluorophosphate. Phys Rev B B6: $4679-4689$

303. Mann AW, Turner AG (1972) Excess calcium fluoride in fluorapatite. Aust $J$ Chem 25: 2701-2703.

304. Dorozhkin SV (2007) A hierarchical structure for apatite crystals. J Mater Sc Mater Med 18: 363-366.

305. Mehmel M (1930) On the structure of apatite. I. Z Kristallogr 75: 323-331.

306. Naray-Szabo S (1930) The structure of apatite (CaF)Ca4(PO4)3. Z Kristallogr 75: 387-398.

307. Nikcevic I, Jokanovic V, Mitric M, Nedic Z, Makovec D, etal. (2004) Mechanochemical synthesis of nanostructured fluorapatite fluorhydroxyapatite and carbonated fluorapatite / fluorhydroxyapatite. J Solid State Chem 177:2565-2574.

308. Montazeri L1, Javadpour J, Shokrgozar MA, Bonakdar S, Javadian S (2010) Hydrothermal synthesis and characterization of hydroxyapatite and fluorhydroxyapatite nano-size powders. Biomed Mater 5: 045004.

309. Zhu Q, Jiang W, Wang H, Shao C (2012) Preparing fluorhydroxyapatite by aqueous precipitation method. Adv Mater Res 412: 167-170.

310. Rodrэguez-Lorenzo LM, Hart JN, Gross KA (2003) Structural and chemical analysis of well-crystallized hydroxyfluorapatites. J Phys Chem B 107:83168320 .

311. Azami M, Jalilifiroozinezhad S, Mozafari M (2012) Calcium fluoride/ hydroxyfluorapatite nanocrystals as novel biphasic solid solution for tooth tissue engineering and regenerative dentistry. Key Eng Mater 493-494: 626631. 
Citation: Dorozhkin SV (2014) Calcium Orthophosphates: Occurrence, Properties and Major Applications. Bioceram Dev Appl 4: 081. doi: 10.4172/2090-5025.1000081

Page 19 of 20

312. Daculsi G, Kerebel LM (1980) Ultrastructural study and comparative analysis of fluoride content of enameloid in sea-water and fresh-water sharks. Arch Oral Biol 25: 145-151

313. Daculsi G, Kerebel LM, Kerebel B (1981) Effects of fluoride on human enamel and selachian enameloid in vitro: a high-resolution TEM and electron diffraction study. Calcif Tissue Int 33: 9-13

314. Prostak KS1, Seifert P, Skobe Z (1993) Enameloid formation in two tetraodontiform fish species with high and low fluoride contents in enameloid. Arch Oral Biol 38: 1031-1044.

315. Dahm S, Risnes S (1999) A comparative infrared spectroscopic study of hydroxide and carbonate absorption bands in spectra of shark enameloid, shark dentine, and a geological apatite. Calcif Tissue Int 65: 459-465.

316. Carr A1, Kemp A, Tibbetts I, Truss R, Drennan J (2006) Microstructure of pharyngeal tooth enameloid in the parrotfish Scarus rivulatus (Pisces: Scaridae). J Microsc 221: 8-16.

317. Lщvъque I1, Cusack M, Davis SA, Mann S (2004) Promotion of fluorapatite crystallization by soluble-matrix proteins from Lingula anatina shells. Angew Chem Int Ed Engl 43: 885-888.

318. Schemehorn BR1, Wood GD, McHale W, Winston AE (2011) Comparison of fluoride uptake into tooth enamel from two fluoride varnishes containing different calcium phosphate sources. See comment in PubMed Commons below J Clin Dent 22: 51-54.

319. Hattab FN (2013) Remineralisation of carious lesions and fluoride uptake by enamel exposed to various fluoride dentifrices in vitro. Oral Health Prev Dent 11: $281-290$

320. Heling I, Heindel R, Merin B (1981) Calcium-fluorapatite. A new material for bone implants. See comment in PubMed Commons below J Oral Implantol 9: 548-555.

321. Gineste L1, Gineste M, Ranz X, Ellefterion A, Guilhem A, et al. (1999) Degradation of hydroxylapatite, fluorapatite, and fluorhydroxyapatite coatings of dental implants in dogs. J Biomed Mater Res 48: 224-234.

322. Agathopoulos S1, Tulyaganov DU, Marques PA, Ferro MC, Fernandes MH, et al. (2003) The fluorapatite-anorthite system in biomedicine.Biomaterials 24: 1317-1331.

323. Yoon BH1, Kim HW, Lee SH, Bae CJ, Koh YH, et al. (2005) Stability and cellular responses to fluorapatite-collagen composites. Biomaterials 26 : 2957-2963.

324. Bogdanov BI, Pashev PS, Hristov JH, Markovska IG (2009) Bioactive fluorapatite-containing glass ceramics. Ceram Int 35: 1651-1655.

325. Nordquist WD, Okudera H, Kitamura Y, Kimoto K, Okudera T,etal. (2011) Part II: Crystalline fluorapatite-coated hydroxyapatite implant material: a dog study with histologic comparison of osteogenesis seen with FA-coated HA grafting material versus $\mathrm{HA}$ controls: potential bacteriostatic effect of fluoridated $\mathrm{HA}$. J. Oral Implant 37: 35-42.

326. Kheradmandfard M, Fathi MH, Ahangarian M, Zahrani EM (2012) In vitro bioactivity evaluation of magnesium-substituted fluorapatite nanopowders. Ceram Int 38:169-175.

327. Sharifnabi A, Fathi MH, Yekta BE, Hossainalipour M (2014) The structural and bio-corrosion barrier performance of Mg-substituted fluorapatite coating on 316L stainless steel human body implant. Appl Surf Sci 288: 331-340.

328. Savarino L, Fini M, Ciapetti G, Cenni E, Granchi D, Baldini N, Greco M, Rizz G, Giardino R, Giunti A (2003) Biologic effects of surface roughness and fluorhydroxyapatite coating on osteointegration in external fixation systems: an in vivo experimental study. J Biomed Mater Res A 66 A: 652-661.

329. Vitkovic M, Noaman MSM, Palou MT, Jantovc S (2009) Potential applications of fluorhydroxyapatite as biomaterials in medicine. Central Eur J Chem 7:246251.

330. Chaari K, Ayed FB, Bouaziz J, Bouzouita K (2009) Elaboration and characterization of fluorapatite ceramic with controlled porosity. Mater Chem Phys 113: 219-226.

331. Qu H1, Wei M (2006) The effect of fluoride contents in fluoridated hydroxyapatite on osteoblast behavior. Acta Biomater 2: 113-119.

332. Bhadang KA1, Holding CA, Thissen H, McLean KM, Forsythe JS, et al (2010) Biological responses of human osteoblasts and osteoclasts to flamesprayed coatings of hydroxyapatite and fluorapatite blends. See comment in
PubMed Commons below Acta Biomater 6: 1575-1583.

333. Theiszova M1, Jantova S, Letasiova S, Palou M, Cipak L (2008) Cytotoxicity of hydroxyapatite, fluorapatite and fluor-hydroxyapatite: a comparative in vitro study. See comment in PubMed Commons below Neoplasma 55: 312-316.

334. Davis TS, Kreidler ER, Parodi JA, Soules TF (1971) The luminescent properties of antimony in calcium halophosphates. J Luminescence 4: 48-62.

335. Mazelsky R, Ohlmann RC, Steinbruegge K (1968) Crystal growth of a new laser material, fluorapatite. J Electrochem Soc 115: 68-70.

336. Ohlmann RC, Steinbruegge KB, Mazelsky R (1968) Spectroscopic and Lase Characteristics of Neodymium-doped Calcium Fluorophosphate. Appl Opt 7 : 905-914

337. An L, Zhang L, Zou J (2009) Fluorapatite: an effective solid base catalyst for Michael addition of indole/pyrrole to nitroalkenes under solventless condition. Chin J Chem 27: 2223-2228.

338. Rogers AF (1912) Dahllite (podolite) from Tonopah, Nevada: voelckerite a new basic calcium phosphate; remarks on the chemical composition of apatite and phosphate rock. Am J Sci, 33: 475-482.

339. Rogers AF (1914) A new locality for voelckerite and the validity of voelckerite as a mineral species. Miner Mag 17:155-162.

340. Voelcker JA. (1883) Die chemische Zusammensetzung des Apatits nach eigenen vollstopndigen Analysen. Ber Dtsch Chem Ges 16: 2460-2464.

341. Gross KA, Berndt CC, Dinnebier R, Stephens P (1998) Oxyapatite in hydroxyapatite coatings. J Mater Sci Mater Med 33: 3985-3991.

342. Hartmann P, Joger C, Barth S, Vogel J, Meyer K (2001) Solid state NMR, $X$-ray diffraction, and infrared characterization of local structure in heat-treated oxyhydroxyapatite microcrystals: an analog of the thermal decomposition of hydroxyapatite during plasma-spray procedure. J Solid State Chem 160: 460468

343. Alberius-Henning P, Adolfsson E, Grins J, Fitch A (2001) Triclinic oxyhydroxyapatite. J Mater Sci 36: 663-668.

344. Wang T, Dorner-Reisel A (2004) Thermo-analytical investigations of the decomposition of oxyhydroxyapatite. Mater Lett 58: 3025-3028.

345. Liu Y, Shen Z (2012) Dehydroxylation of hydroxyapatite in dense bulk ceramics sintered by spark plasma sintering. J Eur Ceram Soc 32: 2691 2696.

346. Van t Hoen C, Rheinberger V, Hiland W, Apel E (2007) Crystallization of oxyapatite in glass-ceramics. J Eur Ceram Soc 27:1579-1584.

347. Duff EJ (1972) Orthophosphates VII. Thermodynamical considerations concerning the stability of oxyapatite, Ca10O(PO4)6, in aqueous media. J Inorg Nuclear Chem 34: 853-857.

348. de Leeuw NH1, Bowe JR, Rabone JA (2007) A computational investigation of stoichiometric and calcium-deficient oxy- and hydroxy-apatites. Faraday Discuss 134: 195-214.

349. Hilgenstock G (1883) Eine neue Verbindung von P2O5 und $\mathrm{CaO}$. Stahl und Eisen, 3: 498.

350. Hilgenstock G (1887) Das vierbasische Kalkphosphat und die Basicitctsstufe des Silicats in der Thomas-Schlacxke. Stahl und Eisen 7: 557-560.

351. Kai D, Fan H, Li D, Zhu X, Zhang X (2009) Preparation of tetracalcium phosphate and the effect on the properties of calcium phosphate cement. Mater Sci Forum 610-613: 1356-1359.

352. Romeo HE1, Fanovich MA (2008) Synthesis of tetracalcium phosphate from mechanochemically activated reactants and assessment as a component of bone cements. J Mater Sci Mater Med 19: 2751-2760.

353. Jalota S, Tas AC, Bhaduri SB (2005) Synthesis of HA-seeded TTCP (Ca4(PO4)2O) powders at $1230 \mathrm{AC}$ from $\mathrm{Ca}(\mathrm{CH} 3 \mathrm{COO}) 2 \square \mathrm{H} 2 \mathrm{O}$ and NH4H2PO4. J Am Ceram Soc 88: 3353-3360.

354. Moseke C1, Gbureck U (2010) Tetracalcium phosphate: Synthesis, properties and biomedical applications. See comment in PubMed Commons below Acta Biomater 6: 3815-3823.

355. Martin I, Brown PW (1993) Hydration of tetracalcium phosphate. Adv Chem Res 5: 115-125.

356. Jillavenatesa A, Condrate Sr RA (1997) The infrared and Raman spectra of 
Citation: Dorozhkin SV (2014) Calcium Orthophosphates: Occurrence, Properties and Major Applications. Bioceram Dev Appl 4: 081. doi: 10.4172/2090-5025.1000081

tetracalcium phosphate (Ca4(PO4)2O). Spectrosc Lett 30: 1561-1570.

357. Nakano T, Kaibara K, Umakoshi Y, Imazato S, Ogata K, etal.(2002) Change in microstructure and solubility improvement of HAp ceramics by heattreatment in a vacuum. Mater Transact 43: 3105-3111.

358. Ellinger RF, Nery EB, Lynch KL(1986) Histological assessment of periodontal osseous defects following implantation of hydroxyapatite and biphasic calcium phosphate ceramics: a case report. Int J Periodont. Restor. Dent 3: $22-33$

359. Nery EB, Lynch KL, Hirthe WM, Mueller KH (1975) Bioceramic implants in surgically produced infrabony defects. J Periodontol 46: 328-347.

360. Pan L, Li Y, Weng W, Cheng K, Song C, etal. (2006) Preparation of submicron biphasic a-TCP/HA powders. Key Eng. Mater 309-311:219-222.

361. Kui C (2007) Slip casting derived a-TCP/HA biphasic ceramics. Key Eng Mater 330-332: 51-54.

362. Li Y1, Kong F, Weng W (2009) Preparation and characterization of novel biphasic calcium phosphate powders (alpha-TCP/HA) derived from carbonated amorphous calcium phosphates. J Biomed Mater Res B Appl Biomater 89: 508-517.

363. Wang R, Weng W, Deng X, Cheng K, Liu X, ,etal. (2006) Dissolution behavior of submicron biphasic tricalcium phosphate powders. Key Eng Mater 309311: 223-226.

364. Li Y1, Weng W, Tam KC (2007) Novel highly biodegradable biphasic tricalcium phosphates composed of alpha-tricalcium phosphate and betatricalcium phosphate. Acta Biomater 3: 251-254.

365. Li Y, Li D, Weng W (2008) In vitro dissolution behavior of biphasic tricalcium phosphate composite powders composed of a-tricalcium phosphate and n-tricalcium phosphate. Key Eng Mater 368-372: 1206-1208.

366. Vani R1, Girija EK, Elayaraja K, Prakash Parthiban S, Kesavamoorthy R, et al. (2009) Hydrothermal synthesis of porous triphasic hydroxyapatite/(alpha and beta) tricalcium phosphate. J Mater Sci Mater Med 20 Suppl 1: S43-48.

367. Lafon JP, Champion E, Bernache-Assollant D (2008) Processing of AB-type carbonated hydroxyapatite Ca10-x(PO4) $(6-x)(\mathrm{CO} 3)(x)(\mathrm{OH})(2-x-2 y)(\mathrm{CO} 3)(\mathrm{y})$ ceramics with controlled composition. J Eur Ceram Soc 28: 139-147.

368. Tonegawa T, Ikoma T, Yoshioka T, Hanagata N, Tanaka J (2010) Crystal structure refinement of A-type carbonate apatite by X-ray powder diffraction. J Mater Sci 45: 2419-2426.

369. Yahia FBH, Jemal M (2010) Synthesis, structural analysis and thermo chemistry of B-type carbonate apatites. Thermochim Acta 50: 22-32.

370. Kannan S, Rebelo A, Lemos AF, Barba A, Ferreira JMF (2007) Synthesis and mechanical behaviour of chlorapatite and chlorapatite / ח-TCP composites. J Eur Ceram Soc 27: 2287-2294.
371. Garcэa-Tuëŕn E1, Couceiro R, Franco J, Saiz E, Guiticn F (2012) Synthesis and characterisation of large chlorapatite single-crystals with controlled morphology and surface roughness. See comment in PubMed Commons below J Mater Sci Mater Med 23: 2471-2482.

372. Zhao P, Zhao T, Ren X, Zhao S, Yang K (2013) Molten salt synthesis of chlorapatite whiskers. Adv Mater Res 668: 302-304.

373. Kannan S, Goetz-Neunhoeffer F, Neubauer J, Ferreira JMF (2008) Ionic substitutions in biphasic hydroxyapatite and n-tricalcium phosphate mixtures: structural analysis by Rietveld refinement. J Am Ceram Soc 91: 1-12.

374. Boanini E1, Gazzano M, Bigi A (2010) lonic substitutions in calcium phosphates synthesized at low temperature. See comment in PubMed Commons below Acta Biomater 6: 1882-1894.

375. Pushpakanth S, Srinivasan B, Sastry TP, Mandal AB(2008) Biocompatible and antibacterial properties of silver-doped hydroxyapatite. J Biomed Nanotechnol 4: 62-66.

376. Zhang Y1, Yin QS, Zhang Y, Xia H, Ai FZ, et al. (2010) Determination of antibacterial properties and cytocompatibility of silver-loaded coral hydroxyapatite. J Mater Sci Mater Med 21: 2453-2462.

377. Kim TN1, Feng QL, Kim JO, Wu J, Wang H, et al. (1998) Antimicrobial effects of metal ions $\left(\mathrm{Ag}^{+}, \mathrm{Cu} 2+, \mathrm{Zn} 2+\right)$ in hydroxyapatite. J Mater Sci Mater Med 9: 129-134.

378. Stanic V, Dimitrijevic S, Antic-Stankovic J, Mitric M, Jokic B, Pleca IB, Raicevic $S$ (2010) Synthesis, characterization and antimicrobial activity of copper and zinc-doped hydroxyapatite nanopowders. Appl Surf Sci 256: 6083-6089.

379. Li Y, Ho J, Ooi CP (2010) Antibacterial efficacy and cytotoxicity studies of copper (II) and titanium (IV) substituted hydroxyapatite nanoparticles. Mater Sci Eng C 30: 1137-1144.

380. Thomas S, Assi P, Marycel B, Correa M, Liberato W,etal. (2008) Yttrium 90-hydroxyapatite, a new radioisotope for chronic synovitis in hemophilia. Haemophilia14: 77.

381. Chinol M, Vallabhajosula S, Goldsmith SJ, Klein MJ, Deutsch KF, etal. (1993) Chemistry and biological behavior of samarium-153 and rhenium-186labeled hydroxyapatite particles: potential radiopharmaceuticals for radiation synovectomy. J Nucl Med 34: 1536-1542.

382. Argḱelles MG, Berlanga ISL, Torres EA (1999) Preparation of $153 \mathrm{Sm}$ particles for radiosynovectomy. J Radioanal Nucl Chem 240: 509-511.

383. O'Duffy E, Clunie G, Lui D, Edwards J, Ell P (1999) Double blind glucocorticoid controlled trial of samarium-153 particulate hydroxyapatite radiation synovectomy for chronic knee synovitis. Ann Rheum Dis 58: 554-558.

384. Ishikawa K (2010) Bone substitute fabrication based on dissolutionprecipitation reactions. Materials 3: 1138-1155. 